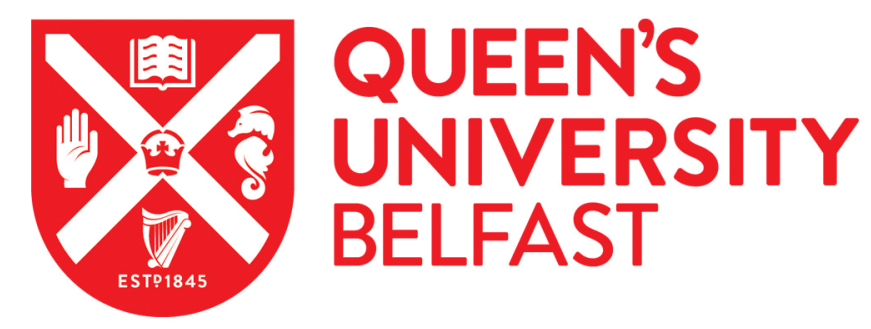

\title{
Domestic waste policy in Ireland - economization and the role of accounting
}

Quinn, M., \& Feeney, O. (2020). Domestic waste policy in Ireland - economization and the role of accounting. Accounting, Auditing \& Accountability Journal, 33(8), 2111-2138. https://doi.org/10.1108/AAAJ-06-2019-4041

\section{Published in:}

Accounting, Auditing \& Accountability Journal

\section{Document Version:}

Peer reviewed version

Queen's University Belfast - Research Portal:

Link to publication record in Queen's University Belfast Research Portal

\section{Publisher rights}

Copyright (c) 2020, Emerald Publishing Limited.

This work is made available online in accordance with the publisher's policies. Please refer to any applicable terms of use of the publisher.

\section{General rights}

Copyright for the publications made accessible via the Queen's University Belfast Research Portal is retained by the author(s) and / or other copyright owners and it is a condition of accessing these publications that users recognise and abide by the legal requirements associated with these rights.

\section{Take down policy}

The Research Portal is Queen's institutional repository that provides access to Queen's research output. Every effort has been made to ensure that content in the Research Portal does not infringe any person's rights, or applicable UK laws. If you discover content in the Research Portal that you believe breaches copyright or violates any law, please contact openaccess@qub.ac.uk. 
Domestic waste policy in Ireland - economization and the role of accounting

Martin Quinn and Orla Feeney

Author details:

Martin Quinn,

Queen’s University Management School, Riddel Hall,

185 Stranmillis Road,

Belfast BT9 5EE,

United Kingdom.

Email: martin.quinn@qub.ac.uk

Orla Feeney,

Dublin City University Business School, Glasnevin,

Dublin 9,

Ireland

Email: orla.feeney@dcu.ie 


\title{
Domestic waste policy in Ireland - economization and the role of accounting
}

\begin{abstract}
Purpose

This paper examines how accounting concepts were utilised in domestic waste collection services in Ireland over the past two decades or so. In comparison to other former 'free' services in the Irish context, the prevalence of accounting concepts has been greater, and delivered a more successful outcome.

\section{Design/methodology/approach}

Drawing on the concepts of calculation, the 'economic' and economization, events around domestic waste policy in Ireland are examined and the increasing prevalence of concepts such as price, cost and profitability in these processes are a focal point. Publicly available documents such as government policy documents, parliamentary records and media reports are utilised to draw out these concepts. The period of analysis is 1996 to 2018.
\end{abstract}

\section{Findings}

The findings reveal the role of accounting concepts in the economization of domestic waste policy in Ireland. The result of the economization process was a fully privatised, profit-oriented, price monitored system.

\section{Research limitation/implications}

This research provides a broad view of accounting concepts in the management of domestic waste. It highlights how waste policy in Ireland travelled through instances of being political and economic over time. The research is limited by its use of secondary data.

\section{Originality/value}

This study highlights how accounting concepts were used in varying ways to bring about a satisfactory solution to domestic waste disposal in Ireland, namely the privatisation of waste services.

Keywords: waste policy, calculation, economization, accounting concepts.

Paper type: Research paper 


\section{Introduction}

[insert Figure 1 about here]

Figure 1 above is from a television program discussing the 2020 election manifesto of an Irish leftwing socialist party, People Before Profit. It reflects a continued tension between the 'profit' motivations of a domestic waste industry and the imperative to reduce waste. People Before Profit, whose name introduces one of the key accounting concepts discussed in this paper, did not deliver on their election promise as they did not gain power. However, their plan to abolish waste charges discourages the behavioural change necessary to reduce waste, a policy encapsulated in European and Irish government policy. They also fail to deal with issues of funding the inevitable rising waste 'costs' which would ensue, given that householders themselves would no longer be responsible. However, the appearance of waste as an issue in their manifesto does highlight that waste collection and disposal includes roles for 'price', 'cost' and 'profit. Additionally, waste reduction/minimisation and recycling are at the core of the notion of the circular economy. As Andersen notes on recycling, "there will be a cut-off point where recycling will become too difficult and burdensome to provide a net benefit” (2007, p.134) i.e. cost becomes too great. Thus, towns, cities, industries, and countries, even if focusing policy on a circular economy, have limits on what is recycled. To reduce the economic cost of recycling efforts, domestic waste producers (i.e. households) are themselves part of the necessary cost-reducing apparatus (Reichenbach, 2008) e.g. by separating waste or paying charges based on the volume of weight produced.

As hinted in Figure 1, domestic waste collection in Ireland today is a delivered entirely by private sector firms, to whom householders pay waste collection charges. This contrasts with most European countries where domestic waste collection is a public service. Ireland's waste management infrastructure is owned and operated by these private firms, meaning competition and regulatory compliance are a focus of government policy. The 'polluter pays' principle underpins Irish and European environmental protection policy, which in terms of domestic households means the cost of managing waste produced should be paid by them. Although Ireland embraced the polluter pays principle at the beginning of the 21st century, the journey from a free governmentfunded service, to a full privately owned pay-by-weight system has been a long one. Such a system charges based on weight collected. Legislation was enacted in Ireland in 2015 to introduce such a system - effective July 1st, 2016 - which included a statutory minimum pay-by-weight charge for all waste types. However, the introduction of the system was postponed for a one-year period due to concerns - but not protest - that consumers would incur higher charges, even if recycling (Irish Times, 2016a). The concerns arose as a view emerged that private waste operators were attempting to manipulate pricing to compensate for lost income/profit if higher levels of recycling materialised. At the end of June 2017, minimum charges were abandoned in favour of a monitored market-based pricing system with the pay-by-weight principle intact.

The above has already revealed how accounting concepts such as cost, price and profit are embroiled in debate and policy around domestic waste management in Ireland. Accounting, to paraphrase Hopwood (1983), is intertwined with organisations, and here also with public policy issues such as waste management. While research on the broader issue of accounting's role in society has progressed hugely since Hopwood's words in 1983, as revealed later, research on its role in waste management is not common. Similar to some prior research, (e.g. Jollands and Quinn, 2017; Warren and Seal, 2018) we draw on actor-network inspired themes to examine how accounting concepts became an increasing part of domestic waste policy in Ireland. In effect, such concepts have been at the core of the creation of a 'waste market' dominated by private companies with profit objectives. Put another way, part of the cost to be incurred by households includes a 
profit margin for waste collection companies. Thus, there is an array of actors in and around domestic waste policy in Ireland. Another difference with waste policy in Ireland is, while there is a cost to households and profits are made, compared to domestic water billing the policy changes over time have not been subject to vociferous protest (see Jollands and Quinn, 2017). This paper examines how accounting concepts have been used in the journey to a pay-by-weight system over time. We utilise the concept of 'calculation' (Callon and Muniesa, 2005), and the notions of the 'economic' and 'economization' defined by Çalışkan and Callon $(2009,2010)$ to examine how accounting concepts have been mobilised in an apparently successful manner - successful in that a stable (and profitable) waste collection 'market' emerged.

The remainder of this paper is structured as follows. First, we outline some literature on domestic waste management and the context of waste management in Ireland, with a focus on policy and economic aspects. This section also includes a review of literature related to the theoretical underpinnings of the paper, as well as our methodological approach. Next, we detail the story of domestic waste in Ireland from 1996 to 2018, revealing the many actors and complexities, integrating aspects of the story with a discussion of events through the lenses of calculation, the 'economic' and economization. We conclude with some reflection, points for future research, and limitations of the research.

\section{Literature}

This section fulfils two functions. First, it sets out the literature on waste management policy with a focus on accounting/economic aspects and on domestic waste policy in Ireland. Second, literature on the methodological approach is summarised.

\section{Waste management policy and the Irish context}

Literature on waste management policy is extensive and a comprehensive review is beyond the scope of this paper. Such literature does highlight concepts and issues which are relevant for this paper, and these are now briefly outlined.

Scharf and Vogel (1994) is a useful starting point on the context of domestic waste management. They noted various volume-based and flat rate charges which were broadly similar in European cities where a weight-based charge applied. A key policy aim of a weight-based charge is to reduce waste through recycling - often referred to as pay-as-you-throw (PAYT) (Reschovsky and Stone, 1994). The literature on the PAYT concept is extensive, and many strengths and weaknesses have been reported - it is the most economically effective method (Dijkgraaf and Gradus, 2004; Husaini et al., 2007). A key aspect of domestic waste policy is collection services, and whether the service is publicly or privately owned. As noted by Domberger and Jensen (1997), competitive tendering can yield cost savings. Eggerth noted "involvement of the private sector in providing [waste] services has become even more complex" (2005. p.229), citing lack of public funds, reduced costs, and lower risk as three main drivers of privatisation. She also noted several issues with privatisation such as "what is the cost of privately vs. publicly provided services? Are users willing and able to pay? How will payments be collected? How will services be funded to low-income areas?” (Eggerth, 2005, p.229) - such issues feature later. Ma and Hipel (2016) supported the comments of Eggerth (2005) and also reported a recognition that "local government still plays an important role in developing policies and strategic plans for private sector participation, monitoring service provisioning, assessing service quality" (2016, p.6). Reeves and Barrow (2000) reported that the potential unit cost savings in Ireland were quite substantial in privatising waste collection (up to 45\%). A later study by Curtis et al (2011, p.264) noted "very little is published on the costs of existing services in Ireland". The lack of cost data was compounded by the fact that many waste operators were either part of a larger group of 
companies or unlimited companies - meaning little public disclosure of accounting data. For this study, we are less interested in actual or accurate costs of the provision of domestic waste collection services, rather on the general notion of cost as a concept (see later). Thus, the lack of literature on costs of waste collection services does not present an issue.

The accounting literature contains some studies which are indirectly relevant here, focusing on environmental accounting, performance measurement and controls within firms. For example, a study by Sundin et al. (2017) noted how waste management plans, waste generation and waste generated feature within firm environmental objectives and reporting. Henri and Journeault (2010) similarly studied management control systems, exploring links between "eco-control" and economic performance and referred to waste reduction, waste minimisation and waste performance measurements. Their study revealed no direct link between eco-control and economic performance, rather a mediating effect in certain contexts, contradicting earlier findings of Lanen (1999). A study by Qian et al. (2011) is interesting in that it explored environmental accounting by local authorities, who in many countries are/were responsible for domestic waste collection. They noted several theoretical perspectives which may explain why managers are motivated to engage in environmental accounting - legitimacy, stakeholder, contingency and institutional perspectives. They also noted a lack of research on environmental accounting in local government. Their findings reported two influences on the level of environmental reporting, namely social structural influences and organisational contextual influences. Interestingly, local authorities cited kerbside collection services, different recycling and garbage collection designs, less available land for new landfill sites and rapidly diminishing landfill spaces more than other factors as reasons for their environmental reporting - some of these are relevant later. In summary, studies from the accounting literature mentioned above do not focus on the broader, societal role of accounting/accounting concepts. Thus, this study builds on extant accounting literature on waste, expanding beyond individual case settings.

Moving to the context of this study, Ireland, consumption patterns accompanying an economic boom in the 1990s impacted the nature and quantity of household waste generated (Boyle, 2001). Ireland was not immune to the throwaway away culture associated with increased consumerism (Strasser, 2000; Fagan, 2003). By the late 1990s, Ireland faced a waste crisis, poor infrastructure and under-developed policies to meet European Union (EU) regulations on waste (Davies, 2003). To meet these EU requirements, the Irish government developed a national framework for waste management to reduce waste to landfill by up to $90 \%$ (Fagan, 2003). Local authorities were charged with responsibility to present an integrated waste management plan, which included landfill expansion, construction of incinerators, the development of recycling infrastructure as well as charging for household waste collection (Davies et al., 2005). Literature on the sociology of waste is relevant to the context of waste management planning. This literature explores civil society's role and individual attitudes and behaviours to waste, i.e. why people behave the way that they do (Yearley, 1995; O’Brien, 1999; Fagan, 2003; Davies et al., 2005) see later description of the 'economic'. The most striking examples are evident in community activism in response to various aspects of the domestic waste story in Ireland. For example, one solution to the country's continuing over-reliance on landfill was to introduce incineration. This was supported by central government and by the private sector, but local communities, environmentalists, scientists and left-wing politicians opposed. Several Irish studies explored this societal resistance to incineration (Boyle, 2001; Davies et al., 2005; Purcell and Magette, 2010), the common theme being public concerns about potential risks from incinerator emissions and an overarching sense that waste prevention was preferable. Another example was in 2003, when the Department of the Environment granted executive power to local authorities to charge for waste services (Protection of the Environment Act, 2003 (52)). Throughout most of the country, domestic 
waste charges were introduced without incident, with protest mainly in Dublin, the capital. This clear divergence was attributed to political geography, with more left-wing political parties concentrated in working class areas of Dublin (Davies, 2007), but it does raise the important issue of context when considering civil society actions. Similar empirical examinations of civil society and waste management in the US, UK and other European countries (see e.g. Davoudi, 2000; Bulkeley et al., 2005; Gonzalez and Healey, 2005; Moulaert and Ailenei, 2005) revealed the importance of context sensitivity when exploring civil society activities (Gerometta et al., 2005; Swyngedouw, 2005). What is particularly interesting is that civil society's role in waste has been regarded in Ireland as confrontational or negative, often referred to as NIMBYism or political opportunism (Davies, 2003). This contrasts with the positive impact that civil organisations have had on waste management in other countries (Liss, 2001; Luckin and Sharp, 2003; ZeroWaste NZ, 2003).

A related body of literature explores individual and household (re-)actions in relation to waste, including a variety of social and institutional factors thought to influence individual attitudes e.g. national wealth and levels of industrialisation (Dunlap et al., 1993), personal norms and awareness of consequences (Hopper and Nielsen, 1991), environmental concern and social norms (Minton and Rose, 1997) and social dilemmas (Bazerman et al. 1996). In an Irish context, Davies et al. (2005) revealed that attitude-action relationships were influenced by personal characteristics and social/institutional factors meaning waste management must be considered within a wider framework of social and political structures. Purcell and Magette (2010) suggested waste behaviours were spatially variable, meaning initiatives designed for one area might ignore the needs of other areas. Like Davies et al. (2005), they also reported that variations in waste service satisfaction and waste management influences were related to the respondents' personal characteristics - e.g. education level, type of accommodation, age - meaning targeted solutions are required to improve rates of diversion from landfill. A common theme across much of this attitudinal research is that individuals are concerned about the environment but have low levels of activity directed towards improvement. This reveals a public and private morality when it comes to environmental issues - people think one way but behave another. In an Irish context, this is evident in the how the public clearly wanted the government to do more to improve circumstances surrounding waste but were unwilling to make personal sacrifices (Drury Research 2000, 2003).

Waste is both local and global - it may be created in one locality, dumped or incinerated in another and flows locally and globally (Fagan, 2003). Examining waste in a 'multiscalar' context involves viewing it as a global, national, local and individual process (Massay, 1992; Marston, 2000) and using this lens opens up the web of players involved in the regulation and management of waste in Ireland (Fagan and Murray, 2006). The detailed account of domestic waste management in Ireland provided later highlights the complex relationships between the different spheres of governance on a European, national and local authority level (EPA, 2000; Boyle, 2001, 2002; Fagan et al, 2001; Taylor, 2001; Davies, 2003). Add to this the role of civil society in the form of community activism (Davies, 2007) and the heightened interest of private enterprise which came with the privatisation wave of the 1990s (Reeves and Barrow, 2000) and a complicated sector, finely balanced between economic, environmental and political interests, can be visualised.

\section{Methodological approach}

This study draws on some actor-network themes from the broader Actor Network Theory (ANT) (Latour, 1986, 1987, 2005; Callon, 1986; Law, 1986) - in particular, the notion of calculation, and in turn, calculative spaces and non-calculative spaces (Callon and Law, 2005), and on the notions of the 'economic' and 'economization' (Çalışkan and Callon, 2009; 2010). Each concept is described in some detail below. 
Calculation, in an ANT sense is not possible without the enrolment of non-human actors (Callon and Law, 2005, p.719), but the effects of these non-human actors can be unpredictable and result in unintended consequences (Callon, 1986). Of relevance here is that the gaining of a desired outcome - the enactment of a pay-by-weight domestic waste collection system - although grounded in history, will have history and origin forgotten (Callon, 1986). Also, the story of domestic waste in Ireland spans several decades and involves several calculations with differing results that "circulate elsewhere in an acceptable way" (Callon and Muniesa, 2005, p. 1231). The use of ANT concepts to analyse the mobilisation of accounting concepts in the process of calculation has an established tradition - e.g. Briers and Chua (2001), Mouritsen et al. (2010), Egan (2014), Jollands and Quinn (2017) and Seal and Warren (2018). In the context of this paper, Hopwood (2009) noted the role of accounting (as a calculative device) in environmental issues would likely not be minimal. In this vein, and of interest here, Egan (2014) and Jollands and Quinn (2017) adopted the notion of calculation in relation to accounting concepts and how water is accounted for.

Calculation is understood in a broad sense; "calculating does not necessarily mean performing mathematical or even numerical operations” (Callon and Muniesa, 2005, p. 1231). Callon and Law refer to it as "qualculation [which] means calculation, whether arithmetical in form or not” (2005, p. 719). Callon and Muniesa (2005) outline calculation as a three-step process. First, entities to be included must be detached, displaced, moved, arranged, and ordered in a single calculative space. They note "an invoice, a grid, a factory, a trading screen, a trading room, a spreadsheet, a clearing-house, a computer memory, a shopping cart [...] can be analysed as calculative spaces, but all will provide different forms of calculation” (Callon and Muniesa, 2005, p.1231). Here, as will be seen, there are many entities and actors (human and non-human) to be ordered in a single calculative space. Second, new associations are formed between assembled entities, and entities are subject to manipulation and transformation. Third is the construction of the accomplished calculation, which produces a result. The result may take the form of an inscription - e.g. an account of waste disposed, a bill based on weight of waste, a market (price) for waste collection. Callon and Muniesa (2005) also highlight three interrelated subtleties that arise in the process of calculation. First, as many actors could be assembled within a calculative space, calculations can be performed in various ways. Second and leading from this, some actors (from past translations) will have means to perform calculations and others will not. Third, and leading from the first two, there can be open discussion, public debate and even protest on how calculations have been assembled.

Some further detail on these subtleties is useful. On the first subtlety, as calculations can be performed in multiple ways, calculation in an ANT-sense is not solely quantitative. As outlined, calculation begins with the assembling of entities in a distinct spatio-temporal frame, a calculative space (Callon and Law, 2005). Thus, when calculation occurs, deciding what is included and excluded is determined, and many outcomes are possible. Additionally, entities included within the calculative space do not pre-date it in the form within the space, but are translated by it (Callon and Law, 2005, p. 719). Thus, as the second step of calculation outlined by Callon and Muniesa (2005) suggests, associations are formed between entities and they are manipulated and transformed. Callon and Muniesa's (2005) second subtlety suggests some actors have means (Law, 1992, p.390) to assemble calculations while others do not. This may include the ability to construct centres of calculation (Latour, 1987) to allow the assembling of calculative spaces. Flowing from the first subtlety, the creation of a calculative space requires decisions on what is included, and what is excluded. Thus, "all calculation builds itself with and against noncalculation” (Callon and Law, 2005, p. 718) and assembling entities within a calculative space implies the removal of counter-calculations. The resources that some actors possess to form powerful (Latour, 1986) 
calculations can and will be utilised to also create non-calculative space. The boundary between a calculative and non-calculative space is typically blurred, overlapping, and reinforcing each other - thus, Callon and Law (2005) state, it is better to think of them as 'other' to each other. Callon and Law (2005) suggest rarefaction and proliferation as strategies for the creation of noncalculative spaces. Rarefaction is the withdrawing of resources and/or relations required for a counter-calculation. Proliferation is the opening up and the inclusion of so many entities interacting, that too much entanglement is constructed and creates incalculability. The second subtlety is also relevant to our focus on the role of accounting concepts such as price, cost and profit. Such accounting concepts can be classified as visionary objects (Briers and Chua, 2001) and are "plastic enough to mould to local practices, while robust enough to carry meaning across differing localities" (Jollands and Quinn, 2017, p.170). They provide a specific notion of how the world should be measured and constructed. They, therefore, act upon what is to be included in a calculative space and what is excluded. On Callon and Muniesa's (2005) third subtlety, if we consider accounting concepts such as price, cost, and profit, these can be open to many understandings. Such variations in understanding can create an opening of discussion and public debate on what should be included in a calculative space, or even if such a space should exist. For example, in the context of a privatised waste collection market in Ireland (Reeves and Barrow, 2000; Curtis et al., 2011;) each private operator could have its own interpretation on pricing and costs, and include or exclude items from calculation, and thus may be a calculative space. However, the private waste collection industry as a whole may also be considered a calculative space (or more precisely a calculative collective space, see Callon and Muniesa, 2005), which may be seen as something to be controlled by government, who may have a different outlook on these same concepts.

This study also draws on the notions of the 'economic' and 'economization' (Çalışkan and Callon 2009, 2010). Taking the 'economic' first, the meaning attached to it by Çalışkan and Callon (2009) is broader than the typical meaning accounting associates to it. Çalışkan and Callon (2009) distinguish a formalist meaning of 'economic' (individual behaviours leading to decisions to fulfil needs) and a substantivist meaning (mechanisms through which society meets its needs). They note that while literature on both the formalist and substantivist view of the economy differ, the individual and collective can be brought together in considering what is 'economic'. In considering domestic waste, individual behaviours could, for example, increase financial means (i.e. personal wealth) by recycling to avoid waste charges; or as a collective, society also needs to reduce waste and create mechanisms and/or policy to encourage individual behaviour. This interaction of the individual and social is apparent from the waste management literature. Çalışkan and Callon (2009) - and earlier Callon (1998) - also refer to 'economization' which refers to "the processes that constitute the behaviours, organizations, institutions and, more generally, the objects in a particular society which are tentatively and often controversially qualified, by scholars and/or lay people, as 'economic'” (p. 370). They note that empirical research on 'economization' has revealed roles played by "techniques, sciences, standards, calculating instruments, metrology and, more generally, material infrastructure" (Çalışkan and Callon, 2009, p. 384) - or materialities as they are termed collectively. While this links to the notion of Callon and Muniesa's (2005) calculation, there are clear links to accounting here - as a technique, science and calculating instrument.

The accounting and broader literature include studies drawing on calculation, economization and related actor-network concepts, and an outline of some relevant papers is now given starting with the accounting literature. Briers and Chua (2001) introduced a visionary object - a new form of boundary object - referring to high level concepts within a community e.g. a precise costing system, but preciseness of cost may be specific to various contexts. Samuel et al. (2005) noted the 
role of accountants and accounting and provided some insights and critique on how medicine and healthcare became 'economic'. In a theoretical paper, Callon (2009) explored the creation of carbon markets, and the role of the accountant as an economic agent who "explicates the effects of climate change on the calculation of costs and investments" (2009, p. 539). He referred to professional accounting organizations as market participants amongst "international organizations or coordination structures” (ibid), clearly identifying accounting and accountants as agents in market formation. Mouristen et al. (2009) focused on how management accounting calculations can be utilised in innovation management and identified several examples of how such calculations play mediating and varied roles in innovation management, appealing to Callon and Muniesa's (2005) understanding of calculation. Preda (2009), in a study of financial markets suggested multiple notions of calculation in financial market trades. One of these "designates the social processes through which entities are selected and transformed in such a way that they become the object of market transactions” (2009, p. 676), again highlighting the broad meaning of calculation. In another financial markets study, Poon (2009) explored how a consumer risk score (a calculative object) became embedded in the entire US mortgage lending market. Muniesa and Linhardt (2009) studied the modernisation of a French research funding agency, which included the introduction of budgetary controls. They noted debates around the mission of the agency began to incorporate "budgetary authorisation [...] a variation on the topic of economization" (2009, p. 557), although they also noted how managing the agency remained politicised. Jollands and Quinn (2017) described the use of accounting concepts in the creation of a calculative space to bring about domestic water charges in Ireland. They highlighted how the concept of cost can have different meanings, as well as how the concept of cost was used as part of a proliferation strategy to prevent counter-calculations. Finally, Warren and Seal (2018) examined electricity generation in the UK and the use of an accounting technique (discounted cash flow) drawing on economization and the concepts of marketization and financialization.

From the broader literature, several studies are worthy of mention. Gregson et al (2013) referred to the economization of ship recycling. They, in their case (the UK's Ship Recycling Strategy) noted how the political became economic, rather than the other way around as envisaged by Çalışkan and Callon (2009). Briefly, a desire by the UK government to avoid being viewed politically as "dumping” ships for recycling, led to framing ship recycling as an economic activity - utilising assaying and assay devices (calculations, measurements) as calculative devices (see Hopwood, 2009), highlighting the link between economization and calculation. Miller and Power (2013), although referring to economizing rather than economization, note the broad role of accounting in economizing (see also Cooper, 2015). They, for example, referred to accounting as territorial (among other roles), noting "calculative instruments of accountancy presuppose and recursively construct the calculable spaces that actors inhabit within organizations and society" (2013, p. 561). This is something Jollands and Quinn (2017) demonstrated empirically (see earlier). Miller and Power (2013) also mention a mediating role of accounting, which is captured in the second step of calculation outlined by Callon and Muniesa (2005) - associations are formed between entities, which are manipulated and transformed.

To sum up on the notion of economization, it has been used in the context of the role of accounting in broader societal issues, suggesting it is a suitable lens for the present study. Based on the above, there are some parallels to the present study in Warren and Seal (2018), but some distinctions should be highlighted. Çalışkan and Callon (2010) refer to marketization as a form of economization which leads to the establishment of markets. The focus of this study is not the formation of a market per se, rather the use of accounting concepts within processes of economization. Additionally, the 'market' for domestic waste in Ireland is not comparable to the large scale and complex markets for electricity in the UK (and other countries), nor to financial 
markets as in studies like that of Preda (2009). Thus, we do not refer to marketization in this study. Also, while a profit motive did enter Irish domestic waste policy through privatisation, to say the sector became "financialized" would be an over claim, as all firms involved were/are privately owned and not subject to financial market forces as UK electricity generators are. Thus, financialization is similarly not utilised here.

The data collection method for this study is to use documentary evidence to follow key actors and processes across time and space in their efforts to bring about a pay-by-weight model for domestic waste. This model ultimately required a payment per $\mathrm{kg}$ of household and food waste to be paid, as first set out in the Waste Management (Collection Permit) (Amendment) Regulations (2016) - described in detail later. Thus, this study follows similar approaches to Jollands and Quinn (2017) who relied on publicly available government documentation and media reports to examine the introduction of domestic water billing in Ireland; and Carroll (2012) who used similar data to explore boundary issues between science and governance in a chronicling of the reclamation of swampland in California. In this study, a detailed examination of European and domestic policy documents, media reports, parliamentary records and legislation (mainly newly enacted legislation) allowed the authors to first set out the time series of events underpinning the evolution of domestic waste policy in Ireland - a full list of documentation reviewed is provided in Appendix 1 .

A theoretically informed analysis of the above documentary sources allowed the authors to trace how calculation, economization and the 'economic' occurred, resulting in a pay-by-weight model and a domestic waste market in Ireland, and revealed the role of accounting concepts (such as cost, price and profit) therein. This approach was guided by other theoretically sensitive explorations of social phenomenon which have provided extensive empirical insight as well as in depth theoretical contribution (Samuel et al, 2005; Callon, 2009; Poon, 2009). Specifically, here, calculation should be understood as defined by Callon and Muniesa (2005) - the three-step process outlined above. Of course, calculation in the numeric sense of accounting in its numeric sense may feature (Hopwood, 2009), through concepts such as cost, price, or profit. Later, two instances of calculation will be outlined in greater detail: 1) the introduction of pay-by-weight waste charges in Ireland, and 2) changes to these charges to include a transparent pricing and a price monitoring mechanism. Likewise, the meaning of 'economic' should also be understood as the meaning presented by Çalışkan and Callon (2009), incorporating a substantivist and formalist view of the economy; and, 'economization' similarly as the processes around behaviours, organizations, institutions and objects society which economic. The two instances of calculation noted above will be described later relative to economization and economic. In the context of Irish waste policy, waste collection is not a public good as consumers may be excluded on non-payment of charges, but uncollected or illegally dumped waste can pose public health issues and/or generate externalities. Thus, waste collection is best described as a merit good - one that is beneficial to society and should be consumed by everyone (see e.g. Morgenroth, 2006) - and aligns to a formalist meaning of 'economic'. However, society (i.e. the Irish state) also has/had a role in delivering this merit good through policy instruments, aligning with a substantivist meaning of 'economic'.

\section{Domestic waste management in Ireland 1996 - 2018}

An overview of events over time is now presented (see also Appendix 2). The earlier parts of this section are contextual and descriptive, provide the waste policy back story, and highlight the mobilisation of accounting concepts. The latter parts engage in conceptual discussion, encompassing the concepts of calculation, the 'economic' and economization. This is typical in actor-network studies, which normally avoid distinction between description and explanation 
(Briers and Chua, 2001; Latour, 1991; Jollands and Quinn, 2017). The events are considered in two time periods. The first is 1996 to 2002, the period from the first legislative efforts to manage waste to the beginning of privatisation. The second, 2003 to 2018, is marked by growing economic considerations such as cost to consumers and the waste industry, as well as an increasing need to manage waste in an environmentally sustainable fashion. This latter point includes changing consumer behaviour and the introduction of a polluter-pays approach. Prior to 1996 local authorities could (and in some cases did) charge for waste collection services under the Local Government (Financial Provisions) (No. 2) Act (1983) and some local authorities levied water charges (Jollands and Quinn, 2017). Barrett and Lawlor (1995) noted that 60\% of the population of Ireland were paying a fixed waste collection charge by 1994. Those not paying for waste collection services were mainly in urban areas, particularly Dublin - it would not be until 2003 that the first Dublin local authority charged for collections. Immediately, the accounting concept of 'cost' is visible, specifically the cost of waste disposal and who should bear that cost. In $60 \%$ of cases local authorities passed the cost onto householders. In Dublin, local authorities themselves bore the cost, giving householders no responsibility, either financially or behaviourally, for waste.

\section{Pre-privatisation, policy and legislation 1996-2002}

In the 1980s, waste management in Ireland was within the remit of local authorities and funded by central government. Lack of infrastructure and investment in waste management practices resulted in local authorities simply providing collection services and landfill facilities (Fagan, 2003). This is similar to the lack of investment noted by Jollands and Quinn (2017) in Ireland's water infrastructure. Throughout the 1980s and 1990s waste generated in Ireland doubled (Stapleton et al., 2000). Ireland's recycling rate was amongst the lowest in the EU and it was reliant on landfill, a solution becoming increasingly problematic in the context of environmental standards (Davies, 2003). By 1998, over $90 \%$ of municipal waste was disposed to landfill and it was estimated that $50 \%$ of all landfill sites in Ireland would be at capacity within three years and capacity breached by 2012 (EPA, 2000). The dominance of landfill at the time can be attributed to its relative cost effectiveness, though increasing social, environmental and health concerns contributed to a revamping of waste strategy in the 1990s (Boyle, 2001). Successive EU directives from 1975 through to 1993 - e.g. the EU Directive on Waste (2008/98) - set out concepts, definitions, and principles on waste management, including the polluter pays principle. These concepts were encapsulated in the Irish legislative framework and the first legislative milestone was the Waste Management Act (1996), which imposed obligations on local authorities to collect, or arrange for the collection of household waste. This is our starting point, as from then waste collection services have evolved from a largely fixed charge service (provided by authorities and private operators) to a full private-sector enterprise - which appears to be quite profitable (Irish Times, 2016a). This transformation implies the role of concepts such as price, cost and profit come to the fore.

With the passing of the Waste Management Act 1996, various policy instruments followed. The first, Waste Management - Changing our Ways (1998), presented a comprehensive policy to modernise Ireland's waste management. It encompassed an integrated approach based on the 'waste hierarchy'- an internationally recognised hierarchy of options for dealing with waste, ranging from waste prevention through to sustainable disposal (Barrett and Lawlor, 1997). The 1998 policy document encouraged a regional approach to increase efficiencies. Ambitious recycling and recovery targets were set to the year 2013 - diversion of 50\% of household waste from landfill, minimum $65 \%$ reduction in biodegradable waste consigned to landfill, recycling $25 \%$ of municipal waste, and recycling $85 \%$ of construction and demolition waste (Dempsey, 1998, p.6). 
Following the 1998 policy document, local authorities formed seven regional groupings from about 32 local authorities, reflecting geographic and demographic considerations. By 2001, 29 local authorities subscribed to waste management plans for the regions of Dublin, North East, Connaught, Midlands, Clare/Kerry/Limerick, South East and Cork City and County. Three local authorities - Donegal, Kildare, and Wicklow - followed individual county plans (Government of Ireland, 2002, p.7). At this time, the cornerstone of EU waste policy was to decrease reliance on landfill (Government of Ireland, 2002, p.7). Limits were placed on the portion of biodegradable municipal waste which could be sent to landfill by 2010. Directive 1999/31/EC set out targets for Ireland; by 2006 the proportions of biodegradable municipal waste to landfill to be reduced to 75\% of the 1995 level; by 2009 it should be halved; by 2016 it should be reduced by 35\% (Government of Ireland, 2002, p.47).

In 2002 Delivering Change - Preventing and Recycling Waste: a policy document set out an agenda to address waste management from the top of the waste hierarchy - waste prevention - by improved recycling levels. A sum of $€ 127 \mathrm{~m}$ in EU/Exchequer funding was made available to support the development of waste recovery and recycling infrastructure. To encourage a change in public behaviour towards recycling, a landfill levy was introduced through the Waste Management (Amendment) Act 2001. Landfill operators, both local authority and private, had to pay this levy to a central government Environment Fund. In the case of private landfill operators, local authorities acted as a collection agent for the levy. The initial levy was $€ 19$ per tonne. In response to the levies, in 2003 the Department of Environment and Local Government (renamed since, see later) extended and amended powers of local authorities to charge for waste services via the Protection of the Environment Act (2003), detailed below. Through this landfill levy, the concept of 'cost' was being mobilised by government as a dissuasive tool to change behaviour in line with government/European policy. Householders either reduced waste or incurred more cost as the landfill levy was passed on to them as an increased waste collection charge. The year 2005 was set as the year by which a pay-by-weight or pay-by-volume system was to be introduced (EPA, 2004). In summary, by 2003, cost had entered Irish waste policy through the landfill levy, which for the first time had the potential to affect all consumers.

\section{Policy and legislation from 2003}

Events from 2003 to 2018 will show how domestic waste collection in Ireland moved from being a free local authority service, to a fully privatised and chargeable service. A resulting waste collection 'market' emerged, with prices monitored by central government. Thus, over time, Ireland's domestic waste collection service has moved from a fully public service - with associated government policies - to a fully private service, which must remain profitable to be sustainable. To begin, an outline of key laws and policies which brought this about is given.

As noted, the Local Government (Financial Provisions) (No. 2) Act (1983) allowed local authorities to charge for services provided. Some did, the main exception being Dublin. In 1993, the Local Government (Dublin) Act (1993) split Dublin county into four new local authority areas. In early 1994, three of the new authorities introduced a flat water charge (see Jollands and Quinn, 2017) - protests followed and charges were rescinded in 1996. These protests likely made Dublin local authorities reluctant to impose waste charges. The Protection of the Environment Act (2003) amended the Waste Management Act 1996, allowing local authorities to "make a charge in respect of the provision of any waste service by, or on behalf of, that authority" (Section 52, 2003). In common with the Waste Management Act (1996), provision of waste services by private enterprise under contract was permitted. Among other things, this reflected a policy towards the movement 
of the 'cost' of waste towards householders, as noted on the previous section. The 2003 Act also gave local authorities powers to recover debts for unpaid charges, and to waive charges in cases of hardship (c.f. Eggerth, 2005). With the passing of the 2003 Act, waste collection charges were introduced to Dublin for the first time (Davies, 2007). While the gradual introduction of charges was opposed throughout Ireland prior to 2003, their introduction to Dublin led to protest against the 'bin tax' (Davies, 2007). Many households refused to pay, local authorities threatened noncollection of waste, there were protests and pickets (Davies, 2007), and several community activists and politicians were jailed or fined for participating in activities such as blockading refuse trucks (Irish Times, 2003a; 2003b; 2003c). The cumulative effect of these actions caused disruption to waste services for many weeks, but perhaps more significantly, the public and political response to this "anti-bin charge" movement signified the extent to which waste charges had become as much a challenge of governance and cost-recovery (following the polluter pays principle) as a challenge of environmental sustainability.

As detailed above, the Waste Management Act (1996) allowed for the provision of waste services by private enterprise, and by 2003 several private companies were operating outside of Dublin. Local authorities traditionally had low waste collection charges with more waivers, meaning they often covered only a portion of costs (Dunne et al., 2008). Flowing from an increasing realisation that waste collection was not efficiently operating as a public service (Reeves and Barrow, 2000), private sector participation increased, coinciding with significantly increased costs of waste services due to stronger environmental standards associated with waste (Dunne et al., 2008). This created a conflict as any private waste sector had to be competitive, whilst at the same time waste policy was a key element of the (Irish) national and European agenda toward environmental sustainability. Accounting concepts thus became more central to the story. It is questionable if a private enterprise motivated by 'profit' could or would successfully carry out activities to meet a broader environmental objective in a landscape governed by European policy and legislation.

In 2004, a Government policy - Taking Stock and Moving Forward - sought to establish where Ireland stood on waste management. By the end of 2003, segregated collection of dry recycling was available to 564,000 households (42\% of all households). The number of public recycling points had doubled since 1998 and there was significantly more civic recycling centres. In addition, the regional groupings formed by the local authorities between 1998 and 2001 resulted in more efficient provision of waste management infrastructure and services and created the possibility for partnership arrangements between local authorities and the private sector (EPA, 2004). At this time, waste collection charges were largely fixed, with collection undertaken by a mixture of local authorities and private operators. It was becoming increasingly apparent, as reflected in the 2004 policy document, that flat waste charges did not cover costs, or incentivise waste reduction or recycling. In 2003, the EU mandated the polluter pays principle be applied to all waste and emphasised the need for a combination of policy measures including voluntary and economic instruments, as well as regulatory command and control measures (European Commission, 2003). Ultimately it was necessary to internalise the cost of waste disposal, making households accept responsibility for waste disposal and encourage behavioural changes (Dunne et al. 2008). Thus here, 'price' could be mobilised as a tool to change behaviour. In linking price to householders' waste reduction efforts, accounting is thus playing a role in enforcing the polluter pays principle. One method to encourage household responsibility is a PAYT system, facilitated by a weighing device integrated in collection trucks. Another method is a pay-per-use system, whereby a fee is charged based on, for example, the number of collections, regardless of weight. This latter method was commonplace in Ireland at the time. Based on the 2004 policy document the Government planned to introduce some form of weight or volume-based charge i.e. mobilise 
price as a tool. A pay-by-volume system was introduced in many areas - typically a charge per collection - and charges of private waste companies rose. Some financial difficulties were faced by households as private waste companies provided no relief to low-income households. A variety of schemes were thus introduced by local authorities offering some waiver of charges to qualifying low-income houses (c.f. Eggerth, 2005). These schemes presented significant cost implications for the local authorities; most used income allocated to other services to subsidise the scheme, with some recovering this cost by levying other users of waste collection services. The number of waiver recipients nationally, but particularly in Dublin, remained relatively static from $2005^{1}$, however, 2010 saw a jump in claimants as Ireland's economic conditions worsened (Irish Times, 2011). In addition, in 2010 Dublin City Council changed the nature of the waiver system, so that recipients paid per lift, but did not pay an annual standing charge. In summary from 2004 to 2012, waste services were largely provided by private waste companies, recycling infrastructure had improved, and most households paid a fixed fee for waste collection.

By 2012 domestic waste collection was fully privatised, Dublin city being the last area. By this time, government policy noted unsustainable dependence on landfill as sites had reached capacity or were due to by 2020, meaning it was imperative to develop alternative approaches (Department of Environment, 2012). The landfill levy had reached €65 per tonne, increasing to $€ 75$ in 2013 - a dissuasive economic instrument (cost) mobilised by government to encourage behaviour change. However, more was needed. The Environment (Miscellaneous Provisions) Act 2015 introduced a pay-by-weight scheme, to be enacted from July 1st, 2016. The Act required all households to pay for waste on a per kilogram $(\mathrm{kg})$ basis, with a view to reducing waste to landfill. The Act set out a minimum mandatory fee per kg for waste types - 11c for residual waste, $6 \mathrm{c}$ for organic waste and zero for recyclables. Here, for the first time in an Irish context, 'price' was mobilised directly to households to encapsulate the polluter pays principle. The waiving or partial waiving of charges for low income households would remain. Under the Act, from July 2015, all waste operators were legally obliged to weigh waste collected and make information available to customers on weights of each bin type collected (see Figure 3 later). This allowed a 12-month window before revised charges applied. It is worth noting that by this time, many waste companies had such a system in place (Irish Times, 2015). In Summer 2016, before the legislation came into effect, a newly elected government faced a backlash - but not protest - from householders who believed waste charges would increase significantly. This was blamed in part on what was 'opportunism' on the part of waste companies, some of whom were increasing service charges (Irish Times, 2016a) - 'profit' motives were driving 'price'. At the same time, the new government was facing questionable stability and protest following the introduction of water charges and thus announced that the new waste charges would be postponed until July 2017. This delay would be accompanied by a six-month awareness campaign on pay-by-weight, costing $€ 1.5 \mathrm{~m}$ and funded by the waste companies - increasing their costs, and reducing profit. During this twelve-month period to July 2017, waste companies were required to provide customers with two bills - one showing the current flat fee system, one showing what they would pay under a pay-by-weight system. In summary, the 2015 to 2017 saw accounting concepts become key in Irish waste management policy. As described, cost, price, and profit were now at play as private waste companies controlled the entire market.

\footnotetext{
${ }^{1}$ According to a report by the Office of the Ombudsman in 2008, about 55,000 households (about $10 \%$ of households) in Dublin were in receipt of a waiver. This cost the Dublin local authorities about $€ 10 \mathrm{~m}$ per annum - see https://www.ombudsman.ie/publications/reports/waste-waiver-schemes-admi/.
} 


\section{Introduction and abolition of minimum pay-by-weight charges}

To understand why waste charges, for some customers at least, would increase under a pay-byweight scheme in Ireland, geographic context is relevant (c.f. Davies, 2007) as there are significant differences in the economics of waste collection. It was believed that the pay-by-weight measures to be introduced in 2016 would impact Dublin more, as the most populated region. The average Dublin household paid an annual flat fee of $€ 250$, while those in other regions paid $€ 350$ (Irish Times, 2016b). As private waste companies had moved into the lucrative Dublin market since 2012, they offered fixed charges as an incentive to attract and retain customers. Fixed waste charges do not encourage consumer behaviour change and evidence suggested that the average household paying a fixed charge disposed $354 \mathrm{~kg}$ more waste annually (Irish Times, 2016b). The chief executive of one large waste companies operating in Dublin, the City Bin Company, emailed customers in 2016 stating that under the current system those living outside of Dublin subsidised the charges of Dublin householders (Irish Times, 2016b). The introduction of pay-by-weight would imply householders outside Dublin would see charges decrease, while Dublin householder charges would increase significantly as prices in Dublin barely reflected the fixed costs of waste recovery costs (Irish Times, 2016b). This illustrates a somewhat disruptive influence of 'price' in this story. By offering competitive prices to secure the lucrative Dublin market, waste companies created a two-tier pricing structure. This had to be brought into balance through the new pay-byweight scheme, triggering the public backlash which temporarily postponed the new charges. Indeed, these lower, mainly flat charges offered to Dublin customers in the first place were incongruent with the goal of behaviour change government policy was striving for.

Pay-by-weight was due to be effective nationwide by 1 July 2017, as outlined above. The government set a minimum mandatory fee per kg for different types of household waste as per the Environment (Miscellaneous Provisions) Act 2015 (see earlier). These represented the minimum waste companies must charge, but they could charge more (Coveney, 2016). On average, in a year a typical Irish family generated $600 \mathrm{~kg}$ of residual waste, $200 \mathrm{~kg}$ of organic waste and $200 \mathrm{~kg}$ of recyclable waste (Coveney, 2016). Table 1 below uses this data to compare an average householder's waste bill with their potential bill under the proposed structure, using the pay-byweight rates for three bin companies, Greyhound, AES and City Bin Company. In all cases, an increase in charges was expected, unless the householder reduced waste. Table 1 also shows the per kg prices are well in excess of the minimum suggested by the Government, and that prices varied by company and clearly captures how 'price' (or cost in the eyes of the householder) can be mobilised in efforts to reduce waste produced by households ${ }^{2}$.

\section{[insert Table 1 about here]}

On June 27th, 2017, the Minister for Communications, Climate Action and Environment, Denis Naughten, announced a scrapping of the mandatory minimum nationwide pay-by-weight charge on the basis that it was unfair, inflexible and did little to encourage recycling. This was arguably in response to the public backlash mentioned earlier. Instead, the government required private waste companies - of which there were 67 at the time (Dáil Éireann, 2017b) - to offer a variety of incentivised pricing options, and the phasing out of fixed flat-rate charges. These incentivised pricing options could include standard charges per lift, per kg, by weight band or weight allowance. All waste collectors were required to provide bins for organic waste. The Minister suggested that such an incentivised charging regime would ensure that if householders segregated more and produced less waste they would pay less, thereby bringing about the behavioural change necessary

\footnotetext{
${ }^{2}$ It should be recognised that packaging also needs to be reduced by producers to reduce waste (see e.g. Beitzen-Heineke et al., 2017), which could also reduce the 'cost' to householders.
} 
to reduce reliance on landfill (Dáil Éireann, 2017c). These new measures were set to be implemented over a phased period of 15 months i.e. be in place in advance of 2019.

As per Callon and Muniesa (2005, p.1231), calculation is a broad process which is "imagining and estimating courses of action associated with [...] things". The three stage process of calculation per Callon and Muneisa (2005) has been described earlier, and based on this, this move to a fully privatised system of domestic waste collection, whereby every citizen in Ireland was in receipt of a waste collection bill from a private waste company is an example of calculation. In the first stage of calculation, a multitude of actors (e.g. laws, waste policy, consumers, costs of public service provision, costs of waste operators, cost to the household, profit, EU directives, private companies) were detached, moved and ordered in a calculative space or spaces (each waste operator). In the second stage, these actors were assembled, manipulated and transformed to reach the third stage - the production of an inscription - a waste bill for every household. The multitude of actors and the complexities of their assembling implied this process took over a decade. However, as revealed in the narrative thus far, accounting concepts (cost, price, and profit) are apparent in the process of calculation. These concepts come more to the fore during a second process of calculation, which we turn to now.

As of mid-2017, just under half of Irish householders paid a flat fee; mostly in Dublin. City Councillors in Dublin criticised the proposed regime allowing private companies to control waste charges and called for regulation (Irish Times, 2017a). Certain that the new proposals would lead to price hikes, particularly in the Dublin area, some opposition political parties voiced their descent - e.g. Solidarity/People before Profit called for an end to private waste companies, arguing waste collection costs be paid from general taxation (Irish Times, 2017b); Sinn Féin called for extensive waivers for the vulnerable (Irish Times, 2017c); and, previous anti-water charge activists promised protest (Irish Independent, 2017). The main opposition party, Fianna Fáil - who underpinned the Fine Gael minority government - called for the appointment of an independent waste regulator (Irish Times, 2017d) to protect householders from sharp price increases. On 4th July 2017, Timmy Dooley of Fianna Fáil proposed a motion to Dáil Éireann (lower house, Irish parliament) to counter a proposal by Minister Naughten. Figure 2 contains a summary of Dooley’s motion.

\section{[insert Figure 2 about here]}

Throughout this paper, accounting concepts - including price, cost, and profitability - are highlighted as important in the story of waste disposal in Ireland. The story reveals how the 'cost' of waste was transferred from government to householders with the intention of changing behaviour by making them financially and behaviourally responsible for waste. Once the waste market was privatised, 'profit' motifs became embroiled in the 'pricing' structures creating competition which influenced householder behaviour. The words of Timmy Dooley as per Figure 2 summarises the story in a comprehensive way and reveals accounting concepts (see italicised, Figure 2). Costs, prices, and profitability are either mentioned directly or inferred. Dooley's comments also reflect that cost can have multiple meanings (Jollands and Quinn, 2017) - i.e. cost to households, waste management cost and as a tool to reduce waste. It is intriguing how the two sets of concepts (accounting and waste management) are almost seamlessly interwoven in Dooley's comments. The motion proposed by Dooley was accepted by Minister Naughten, particularly with reference the appointment of a regulator, as follows:

I will establish a pricing watchdog monitoring unit that will provide monthly reports on pricing developments and I will ask the Competition and Consumer Protection Commission, CCPC, to report on the operation of the household waste collection market. This will inform 
the future development of national waste management policy before year end, which will provide an evidence base to establish a regulator to prevent price gouging. This unit will comprise representatives from the CCPC, my Department, a consumer representative from an organisation such as the Society of St. Vincent de Paul and an external economic expert with market knowledge (Dáil Éireann, 2017b, p.98).

The italicised words of Minister Naughten above again highlight accounting concepts. Prices were to be monitored and controlled; in other words, the accounting concept of price, which could impact waste companies' profits and/or cost structures, was mobilised by government to appease public and political opposition. Additionally, the inclusion of a representative from the Society of St. Vincent de Paul (a charity who aid the poor), highlights another meaning of cost, cost to the consumer and the impact it could have on household incomes (c.f. Eggerth, 2005; Jollands \& Quinn, 2017).

The parliamentary debate on the above motion on 4th July 2017 raised another interesting point, on profitability of waste companies. It was noted by Bríd Smith (People Before Profit party) that many waste companies had not filed detailed financial statements with the companies registrar for many years, as they were unlimited companies and could avail of filing exemptions. It was suggested by Smith that waste companies be required to file financial statements in Ireland to obtain a waste operator permit, and that they are very profitable. Smith noted:

How are we supposed to know whether these companies are losing money, are profitable or are going to the wall? There is a proliferation of them. As in the case of Tony Soprano ${ }^{3}$, it was no accident that these companies got involved in waste management. (Dáil Éireann, 2017b, p.107).

In reply Minister Naughten simply noted “the law was changed” (Dáil Éireann, 2017b, p.107). The Minister was referring to the passing of the Companies (Accounts) Act 2017, which under Section 78 changed Irish company law to imply only pure unlimited liability companies could avail of reporting and filing exemptions. The emergence of this new Act was not related to waste policy, rather to enact EU Directive 2013/34/EU on the accounts of groups of companies. The comment by Smith above highlights the fact that waste companies formed as unlimited companies to hide costs, profits, and assets from competitors - and others. This new Act removed this capability, and thus accounting concepts could enter the debate on waste in a more open and transparent way - at least post 2019 when the first financial statements under the Act would be publicly available.

[insert Table 2 about here]

[insert Figure 3 about here]

Following from the parliamentary debates mentioned above, by the end of 2017, most waste companies had changed their systems and there was little evidence of opposition or protest to the proposed charging structure. The promised waste regulator emerged in September 2017 as the Price Monitoring Group (PMG). The PMG operates under the Minister's remit, is chaired by an independent consumer expert and is comprised of members of the Minister's department and Central Statistics Office of Ireland staff. The PMG produced its first report in December 2017, and its periodic reports show anonymised full price details for waste collection. By the end of 2018, all waste companies had complied with the new regulations, and according to the PMG's

${ }^{3}$ A fictional mafia boss popularised in the HBO series The Sopranos. 
December 2018 report, prices remained relatively stable, although 51 different price plans existed nationally. The price plans all included a standard service charge, with additional charges by kg, per lift, or per kg in excess of allowance. The December 2018 report noted that "there does appear be a migration towards one pricing plan across the majority of firms; service charge including a weight allowance plus per kg charge for excess above allowance”. While some operators still charged on a per lift basis (regardless of weight), those who had moved to this more common policy exhibit varying price policies - some examples are shown in Table $2^{4}$. While the waste companies in Tables 1 and 2 are not comparable, it is noticeable that the annual charges are closer to the charges as of 2017 (see Table 1) and include a price (cost to householder) incentive to avoid additional charges. While we cannot be certain due to the anonymity of the waste companies in the PMG reports, it is likely differing price structures reflect the capabilities and efficiencies of each operator. For example, larger operators (such as Panda Waste) process organic waste into renewable energy for sale on the open market and can justify no charge for the collection of such waste. Economies of scale are also a likely factor - for example, company $\mathrm{H}$ in Table 2 may not have sufficient volume of recyclable waste and must charge householders. Some waste operators also provided web-based tools and/or apps to customers to provide data on the volume of waste collected - see e.g. Figure 3. Such tools allow customers to monitor waste and take action to reduce excess cost and/or stay within their allowances. The industry is experiencing, perhaps for the first time, a relative consistency, at least in pricing structures used by waste companies. After its initial proposal in 2004, householders were now experiencing 'pay-by-weight', meaning price has been successfully mobilised to change behaviour - although this necessitated some control of the private market in the form of the PMG.

The developments giving rise to a relatively consistent and transparent pricing mechanism, and giving consumers some control over waste charges, is a second example of calculation. While having similar actors, new actors (e.g. the PMG, new laws) and various courses of action were considered before an outcome was apparent. In this calculation, the assemblage/manipulation of actors into a calculative space was easier, as much moving and ordering had been done in the first process of calculation. Protest around water charges (see Jollands and Quinn, 2017) effected the manipulation of actors with the government more conscious of costs to end consumers. At the same time, private firms must cover 'costs' and set a 'price' to yield a 'profit'. New associations were formed, e.g. interactions between the PMG and waste companies, and entities were transformed e.g. waste companies changed their pricing structures, the government abandoned minimum charges. The result of this second process of calculation was a relatively stable pricing structure (see Table 2) which encapsulated the polluter pays principle - excess waste was chargeable - and allowed waste operators to make a profit. An inscription from this calculation was a similar domestic waste bill, but also tools for householders to monitor waste volumes (see Figure 3). The prices charged were not set by government policy, although the government still had a role in the calculation process (c.f. Ma and Hipel, 2016). The PMG - a centre of calculation - ensured transparent pricing and prevented 'Tony Soprano' type profitability. At the same time, by not insisting on a minimum price, the government allowed fair and transparent prices to be set which reflected cost structures of each waste company, and made the polluter pay for excess waste (see Figure 2 and Table 2). This instance of calculation (and the previous one) were inclusive of a multitude of actors, and thus incalculability features by means of proliferation. Also, the government, through laws and waste policies - which only the government had means to do (Law, 1992) - utilised rarefaction to prevent counter-calculations and create a relatively standard waste

\footnotetext{
${ }^{4}$ Data from December 2019 shows little change in prices compared to Table 2 - see https://www.dccae.gov.ie/en-ie/environment/topics/waste/the-householder-and-waste/household-wastecollection/price-monitoring-group/monthly-analysis/Pages/Monthly-Analysis-2019.aspx.
} 
collection 'market' nationally. The role of accounting concepts - price, cost, profit - is quite apparent in this second calculation.

The two calculations described are linked to economization and the 'economic' per Çalışkan and Callon (2009) and we now turn to these concepts in the context of the present paper. The formalist meaning of 'economic' and the substantivist meaning have been described earlier. Waste collection in Ireland aligns to a formalist meaning of 'economic' - individual behaviours leading to waste collection and avoidance of health risks and reduced cost to the Irish household. However, there is also a dual role of the individual and society. While individuals needs may be met directly through a waste market scenario as described here, or through indirect taxation, the state also had a role - a substantivist meaning of 'economic'. The Irish government, over time, chose a market mechanism for domestic waste collection for reasons of cost efficiency (see Reeves and Barrow, 2000). This journey, and the overlapping of society's need to manage its waste with the private waste market's need to be profitable, is underpinned by the two calculation processes discussed above - and the accounting concepts embodied therein. Çalışkan and Callon (2009) highlighted the role of techniques, sciences and other materialities in the process of economization; "material devices [are] part and parcel of the processes of economization" (Çalışkan and Callon, 2009, p.384). The accounting concepts as described above are a key element in the technical arrangements and materials devices in the economization of domestic waste collection in Ireland. They are in the words of Warren and Seal (2018), an economic prosthetic which supported the twists and turns of various actors over time and space e.g. government, polices and private sector waste companies.

The economization process described here also raises some interesting findings and contributions to extant research on economization. The Irish government, faced with increasing EU regulation and lack of funding, used cost to determine privatisation as a viable solution to save money (Reeves and Barrow, 2000) and meet legal requirements on waste disposal and landfill. This is similar to the findings of Gregson et al (2013) in that the political (waste policy) became economic in the 2000s as the Irish government allowed local authorities to privatise waste collection - with the exception of Dublin as detailed earlier. For many years, the economic was to the fore (and accounting concepts), until the Irish government attempted to introduce a minimum waste charge (see Table 1). Thus, the economic became political as suggested by Muniesa and Callon (2007). Potential increased costs to consumers led to some political concern - possibly borne out of protest against domestic water charges (see Jollands and Quinn, 2017). However, the Irish government had already chosen institutional and technical arrangements which included private for-profit firms in the economization of domestic waste two decade previous. These firms now also had to consider their costs and price for waste collection to earn profit. The government - see Figure 2 - wanted fair and transparent pricing for consumers, but at the same time private firms would not enter a market where price is insufficient to make a profit. The resulting PMG, a centre of calculation (and a new actor) utilised accounting data (waste collection price) as a technical instrument to ensure that the 'economic' outcome of the domestic waste market in Ireland meets the varied, interlinked and often complex objectives of delivering waste collection as a merit good i.e. at a cost acceptable to householders, allowing waste companies earn profit and reduce waste going to landfill. Here, in the latter stages of the forming of a waste 'market' in Ireland, the interaction of political and economic is quite apparent, and over course of the time the political became economic, then political again (2017) and economic finally, albeit it with a political watchdog in the PMG. The latter point is interesting in that if 'cost' to the householder is a measurement, it is a more accurate and controlled measure than the assay devices as described by Gregson et al. (2013). 
It is worth noting that the processes described here has also brought about accounting for waste itself. As a merit good, individuals likely wish to have their waste collected, but they may also have environmental concerns and/or financial concerns (such as ability to pay). On the latter, the government supported some waivers - for medical reasons only ${ }^{5}$, with low income waivers no longer available. On both, as seen in Figure 3, consumers can monitor (c.f. measurement as per Gregson et al., 2013) the volumes/cost of waste disposed of and can account to themselves on individual environmental concerns; and, at the same time monitor for potential additional costs which may be quite relevant to low income households. The technical arrangements which permit the production of data such as that shown in Figure 3 (tags embedded within bins and weighing devices on collection vehicles) also assist in the process of delivering a societal (and regulatory) need to reduce waste volumes to landfill.

Finally, although contributing to waste management literature is not our key purpose, two points are worth noting. First, Davies (2007) noted geographic context was relevant to attitudes to waste charges. Here, it has been revealed that there are also significant differences in the economics (and profitability) of waste collection geographically. Second, while Ma and Hipel (2016) noted the role of local authorities in a privatised waste sector, the role of central government, as an actor with power and resources to undertake powerful calculations (Latour, 1986) - the creation of the PMG - has been highlighted. Arguably, this was a key to the success of the Irish waste privatisation.

\section{Final remarks}

This paper has highlighted the role of accounting concepts in domestic waste collection services in Ireland over time, and its economization. The cost (price) to a householder in Ireland since the end of 2018 not only incorporates the polluter pays principle, but also includes a (controlled) profit margin of private firms. The dual needs of individuals and society in the delivery of a merit good have been achieved through the bringing together of actors over an extended period. However, the paper has also highlighted how policy makers should be aware of effects of profit motives, which in the Irish context made the economic political in more recent years, resulting in political monitoring of prices charged by waste companies.

This study is limited by its reliance on secondary data. While the sources used are extensive and cover a prolonged time frame, primary data may yield more insights. However, the paper opens the field of domestic waste collection to more general accounting research. The literature review earlier revealed little published work on the societal role of accounting/accounting concepts and domestic waste collection, although as Hopwood (2009) suggested calculation(s) would have a strong role in environmental issues. One interesting avenue of future research would be study how (or if) accounting features in similar processes of economization in former public services in other jurisdictions. Another interesting area is the role of accounting/accounting concepts in decisions on waste recycling and waste recovery e.g. consideration of costs and revenues on decisions around waste-to-energy projects. The impact of overpackaging on householders may also be a fruitful area for research on interactions between accounting concepts and the polluter pays principal - current movements by retailers to reduce or eliminate plastic and other packaging could be an interesting case. Another useful area of research is on the impact of cost to households, and low-income households particularly. For example, a lack of waivers may have public health and other cost implications if low income householders dump waste due to unaffordability.

\footnotetext{
${ }^{5}$ As per Minister Naughten, “an annual support of $€ 75$ will be introduced for persons with lifelong/long-term medical incontinence” - see https://www.dccae.gov.ie/en-ie/news-and-media/press-releases/Pages/HouseholdWaste-Collection-Charging-Arrangements.aspx . As of late 2019, this waiver had not been enacted.
} 


\section{References}

Andersen, M. S. (2007), “An introductory note on the environmental economics of the circular economy”, Sustainability Science, Vol. 2, No. 1, pp. 133-140.

Barrett, A. and Lawlor, J. (1997), "Questioning the waste hierarchy: the case of a region with a low population density”, Journal of Environmental Planning and Management, Vol. 40, No. 1, pp. 19-36.

Barrett, A. and Lawlor, J. (1995), “The economics of solid waste management in Ireland”, Policy Research Series, No. 26, Dublin: ESRI.

Bazerman, M.H., Wade-Benzoni, K.A., Benzoni, F., (1996). A behavioural decision theory perspective to environmental decision making, in: Messick, D.M., Tenbrunsel, A. (Eds.), Ethical Issues in Managerial Decision Making, Russell Sage Foundation, New York.

Beitzen-Heineke, E. F., Balta-Ozkan, N., \& Reefke, H. (2017). The prospects of zero-packaging grocery stores to improve the social and environmental impacts of the food supply chain. Journal of Cleaner Production, Vol. 140, No. 3, pp. 1528-1541.

Bliss, M. (1974), A Living Profit: Studies in the Social History of Canadian Business, 18831911, Toronto: McClelland and Stewart

Briers, M. and Chua, W. F. (2001), "The role of actor-networks and boundary objects in management accounting change: A field study of an implementation of activity-based costing”, Accounting, Organizations and Society, Vol. 26, No. 3, pp. 237-269.

Bulkeley, H., Watson, W., Hudson, R. and Weaver, P. (2005), "Governing municipal waste: towards a new analytical framework", Journal of Environmental Policy and Planning, Vol. 7, No. 1, pp. 1-23.

Burnett, R. D., and Hansen, D. R. (2008), "Eco-efficiency: Defining a role for environmental cost management”, Accounting, Organizations and Society, Vol. 33, No. 6, pp. 551-581.

Boyle, (2001), "Cleaning up after the Celtic Tiger: the politics of waste management in the Irish republic”, Journal of the Scottish Association of Geography Teachers, Vol. 30, pp. 71-91.

Boyle, (2002), “Cleaning up after the Celtic Tiger: scalar 'fixes' in the political ecology of Tiger economies”, Transactions of the Institute of British Geographers, Vol. 27, No. 2, pp. 111125.

Briers, M. and Chua, W. F. (2001), "The role of actor-networks and boundary objects in management accounting change: A field study of an implementation of activity-based costing", Accounting, Organizations and Society, Vol. 26 No. 3, pp. 237-269.

Çalışkan, K., and Callon, M. (2009), "Economization, part 1: shifting attention from the economy towards processes of economization”, Economy and Society, Vol. 38, No. 3, pp. 369-398.

Çalışkan, K., and Callon, M. (2010), "Economization, part 2: a research programme for the study of markets”, Economy and Society, Vol. 39, No. 1, pp, 1-32.

Callon, M. (1986), "Some elements of a sociology of translation: domestication of the scallops and the fishermen of St Brieuc Bay", in Law, J. (Ed.), Power, action and belief: a new sociology of knowledge? London, Routledge, pp. 196-233.

Callon, M. (1998), “An essay on framing and overflowing: economic externalities revisited by sociology", in Callon, M. (Ed.), The Laws of the markets, Oxford, Blackwell Publishers, 244-269.

Callon, M. (1999), “Actor-network theory-the market test”, in Law, J. and Hassard, J. (Eds.), Actor network theory and after, Oxford, Blackwell Publishers, pp.181-195.

Callon, M. (2007), “An Essay on the Growing Contribution of Economic Markets to the Proliferation of the Social”, Theory, Culture and Society, Vol. 24, No. 7-8, pp. 139-163.

Callon, M. (2009). "Civilizing markets: Carbon trading between in vitro and in vivo experiments”, Accounting, Organizations and Society, Vol. 34, No. 3-4, pp. 535-548. 
Callon, M., and Law, J. (2005), “On qualculation, agency, and otherness”, Environment and Planning D: Society and Space, Vol. 23, No. 5, pp. 717-733.

Callon, M., and Muniesa, F. (2005). “Economic Markets as Calculative Collective Devices”, Organization Studies, Vol. 26, No.8, pp. 1229-1250.

Carroll, P. (2012), "Water and technoscientific state formation in California”, Social Studies of Science, Vol. 42, No. 4, pp. $489-516$.

Cooper, C. (2015). "Entrepreneurs of the self: The development of management control since 1976”, Accounting, Organizations and Society, Vol. 47, pp. 14-24.

Coveney, S. (2016), “Briefing on Introduction of Pay-by-Weight for Household Waste”, May 20th.

Curtis, J., Lyons, S., and O’Callaghan-Platt, A. (2011), “Managing household waste in Ireland: behavioural parameters and policy options”, Journal of Environmental Planning and Management, Vol. 54, No. 2, pp. 245-266.

Dáil Éireann (2017a). Waste Disposal Charges, available at http://oireachtasdebates.oireachtas.ie/debates\%20authoring/debateswebpack.nsf/takes/dail2 017062700030 ?opendocument, accessed June 29th, 2017.

Dáil Éireann (2017b). Official Report - 4 July 2017, Vol. 956, No. 3

Dáil Éireann (2017c), Dail Eireann Debate, Tuesday 27th June 2017, Question 63, available at. http://oireachtasdebates.oireachtas.ie/debates\%20authoring/debateswebpack.nsf/takes/dail2 017062700030?opendocument, accessed December 8th, 2017

Davies, A. (2007), “A wasted opportunity? Civil society and waste management in Ireland”, Environmental Politics, Vol. 16, No. 1, pp. 52-72.

Davies, A. (2003), "Waste wars - public attitudes and the politics of place in waste management strategies”, Irish Geography, Vol. 36, No. 1, pp. 77-92.

Davies, A., Fahy, F., Taylor, D., (2005), 'Mind the gap! Householder attitudes and actions towards waste in Ireland', Irish Geography, Vol. 38, No. 2, pp. 151-168.

Davoudi, S. (2000), "Planning for waste management: changing discourses and institutional relationships”, Progress in Planning, Vol. 53, pp. 165-216.

Department of Environment (2012), A resource opportunity: waste management in Ireland, Dublin: Department of Environment, Community and Local Government.

Dempsey, N. (1998), Waste Management - Changing our Ways, Dublin: Department of Environment and Local Government.

Dijkgraaf, E., and Gradus, R. H. (2004), “Cost savings in unit-based pricing of household waste: The case of The Netherlands”, Resource and Energy Economics, Vol. 26, No. 4, pp. 353371.

Domberger, S., and Jensen, P. (1997), "Contracting out by the public sector: theory, evidence, prospect”, Oxford Review of Economic Policy, Vol. 13, No. 4, pp. 67-78.

Drury Research, (2000). Attitudes and actions: a national survey on the environment. Dublin: DoEHLG.

Drury Research, (2003). Attitudes and actions: a national survey on the environment. Dublin: DoEHLG.

Dunne, L., Convery, F. J. and Gallagher, L., (2008). “An investigation into waste charges in Ireland, with emphasis on public acceptability”, Waste Management, Vol. 28, No. 12, pp. 2826-2834.

Dunlap, R., Gallup Jr., G., Gallup, A., (1993). Global environmental concern: results from an international public opinion survey, Environment, 35 (9), 7-15.

Egan, M. (2014), “Making water count: water accountability change within an Australian university”, Accounting, Auditing and Accountability Journal, Vol. 27, No. 2, pp. 259-282.

Eggerth, L. L. (2005), “The evolving face of private sector participation in solid waste management”, Waste Management, Vol. 25, No. 3, pp. 229-230. 
European Commission (2003). Toward a thematic strategy on waste prevention and recycling. Brussels: European Commission

EPA (2000). National Waste Database Report 1998. Wexford: Environmental Protection Agency.

EPA (2004). Waste Management - Taking Stock and Moving Forward. Wexford: Environmental Protection Agency.

EPA (2014), National Waste Report 2012. Wexford: Environmental Protection Agency.

Epstein, G.A. (2005), “Introduction: financialisation and the world economy”, in Epstein, G.A. (Ed.), Financialisation and the World Economy, Edward Elgar, Cheltenham, pp. 3-16.

Fagan, G. H., (2003), “Sociological reflections on governing waste”, Irish Journal of Sociology, Vol. 12, No. 1, pp. 67-84.

Fagan. G. H., O’Hearn, D., McCann, G. and Murray, M. (2001), "Waste management strategy: a cross border perspective”, Working Paper Series 2/2001, Maynooth: National University of Ireland.

Fagan, G. H. and Murray, M., (2006). “Green Ireland? Waste in its social context”, in Bartley, B. and Kitchan, R., (eds), Understanding Contemporary Ireland. UK: Pluto Press.

Gerometta, J., Haussermann, H. and Longo, G. (2005), "Social innovation and civil society in urban governance: strategies for an inclusive city”, Urban Studies, Vol. 42, No. 11, pp., 2007-2021.

Gonzalez, S. and Healey, P. (2005), “A sociological institutionalist approach to the study of innovation in governance capacity”, Urban Studies, Vol. 42, No. 11, pp. 2055-69.

Government of Ireland (2002), Delivering Change: Preventing and Recycling waste, a policy statement, Dublin: The Stationery Office.

Gregson, N., Watkins, H., \& Calestani, M. (2013). "Political markets: recycling, economization and marketization”, Economy and Society, Vol. 42, No.1, pp. 1-25.

Henri, J. F., and Journeault, M. (2010), "Eco-control: The influence of management control systems on environmental and economic performance”, Accounting, Organizations and Society, Vol. 35, No. 1, pp. 63-80.

Hopper, J.R., Nielsen, J.M. (1991), "Recycling as altruistic behavior: normative and behavioural strategies to expand participation in a community recycling program”, Environment and Behavior, Vol. 23, pp. 195-220.

Hopwood, A. G. (1983), "On trying to study accounting in the contexts in which it operates”, Accounting, Organisations and Society, Vol. 8, No. 2-3, pp. 287 -305.

Hopwood, A. G. (2009), “Accounting and the environment”, Accounting, Organizations and Society, Vol. 34, No. 3-4, pp. 433-439.

Husaini, I. G., Garg, A., Kim, K. H., Marchant, J., Pollard, S. J., and Smith, R. (2007), "European household waste management schemes: Their effectiveness and applicability in England”, Resources, Conservation and Recycling, Vol. 51, No. 1, pp. 248-263.

Irish Times (2017a). Dublin city councillors vote against ban on flat rate bin charges, July 3rd.

Irish Times (2017b). New bin charges: what do they mean and how much will they be, June 28th

Irish Times (2017c). Mary Lou fires opening salvo in latest round of 'Utility Wars' , June 28th.

Irish Independent (2017). How bin charges are set to rise by at least $€ 30$ - and it's only the beginning, July 1 st.

Irish Times (2017d). Watchdog to monitor cost of new waste charges, Taoiseach says, July 4th.

Irish Times (2017e). Most people in Cork already pay-by-weight: Abolition of flat-rate refuse charges will have little impact in many areas, July 5th

Irish Times (2017f). Lack of competition widespread in waste sector, July 5th.

Irish Times (2016a). Bin charges to be frozen for 12 months after FF backs deal, June 22nd.

Irish Times (2016b). Controversy still surrounds pay-by-weight bin charge system, June 24th.

Irish Times (2015). Finding ways to save money on bin charges is not a waste of time, Sept 1st. 
Irish Times (2011). Low income households wrongly sent charge bills, Aug 22nd.

Irish Times (2003a). More bin protests due as Higgins, Daly jailed, Sep 20th

Irish Times (2003b). 2,000 rally in Dublin against bin charge; Campaigners demand release from prison of Socialist TD Joe Higgins and Cllr Clare Daly, Sep 23rd.

Irish Times (2003c), Anti-bin tax campaign is just the opening shot for Higgins. Oct 20th.

IWMA (2017). List of Members, available at http://iwma.ie/about-us/list-of-iwma-members/, accessed June 29th, 2017.

Jollands, S. and Quinn, M. (2017), "Politicising the sustaining of water supply in Ireland - the role of accounting concepts”, Accounting, Auditing and Accountability Journal, Vol. 30, No. 1, pp. 164-190.

Jones, T.C. and Dugdale, D. (2002), "The ABC bandwagon and the juggernaut of modernity”, Accounting, Organizations and Society, Vol. 27, No. 1-2, pp. 121-163.

Lanen, W. N. (1999), "Waste minimization at 3M Company: A field study in non-financial performance measurement”, Journal of Management Accounting Research, Vol. 11, No. $29-43$.

Latour, B. (1986), “The power of associations”, in Law, J. (Ed.), Power, action and belief: a new sociology of knowledge? London, Routledge, pp. 264-280.

Latour, B. (1987), Science in action: how to follow scientists and engineers through society. Cambridge, Mass. Harvard University Press.

Latour, B. (1991), "Technology is society made durable", in Law, J. (Ed.), A Sociology of monsters: essays on power, technology, and domination. Routledge, London, pp. 103-131.

Latour, B. (2005), Reassembling the social: an introduction to actor-network-theory. Oxford, Clarendon.

Law, J. (1986), “On the methods of long distance control: vessels, navigation, and the Portuguese route to India”, in Law, J. (Ed.), Power, action and belief: a new sociology of knowledge? London, Routledge, pp. 234-263.

Law, J. (1992), "Notes on the theory of the actor-network: Ordering strategy, and heterogeneity", Systems Practice, Vol. 5, No. 4, pp. 379-393.

Liss, G. (2001), Del Norte County: On the Road to Zero Waste, Loomis, CA: Gary Liss and Associates.

Luckin, D. and Sharp, L. (2003), Sustainable Development in Practice: Community Waste Projects in the UK, Bradford: University of Bradford.

Marston, S. (2000), “The social construction of scale”, Progress in Human Geography, Vol. 24, pp. 219-242.

Massay, D. (1992), "Politics and space-time”, New Left Review, Vol. 196, pp. 65-48.

Ma, J., and Hipel, K. W. (2016), "Exploring social dimensions of municipal solid waste management around the globe-A systematic literature review”, Waste Management, Vol. 56, pp. 3-12.

Michaud, K., Carlisle, J. E. and Smith, E. (2008), "Nimbyism vs. environmentalism in attitudes toward energy development”, Environmental Politics, Vol 17, No. 1, pp. 20-39.

Miller, P., \& Power, M. (2013). “Accounting, organizing, and economizing: Connecting accounting research and organization theory”, The Academy of Management Annals, Vol. 7, No. 1, pp. 557-605.

Minton, A.P., Rose, R.L., (1997), “The effects of environmental concern on environmentally friendly consumer behaviour: an exploratory study”, Journal of Business Research, Vol 40, No. 1, pp. 37-48.

Morgenroth, E. (2006), "Waste collection, double taxation and local finance” in Callan, T. and Doris, A/ (Eds) Budget Perspectives 2006. Dublin: Economic and Social Research Institute. 
Moulaert, F. and Ailenei, O. (2005), "Social economy, third sector and solidarity relations: a conceptual synthesis from history to present”, Urban Studies, Vol. 42, No. 11, pp. 20372053

Mouritsen, J., Hansen, A., \& Hansen, C. Ø. (2009). "Short and long translations: Management accounting calculations and innovation management”, Accounting, Organizations and Society, Vol. 34, No, 6-7, pp. 738-754.

Mouritsen, J., Mahama, H. and Chua, W. F. (2010), “Actor-network theory and the study of inter-organisational network relations", in Hakansson, H., Kraus, K. and Lind, J. (Eds.), Accounting in Networks. London: Routledge, pp. 292-313.

Muniesa, F., and Linhardt, D. (2011), "Trials of explicitness in the implementation of public management reform", Critical Perspectives on Accounting, Vol. 22, No. 6, pp. 550-566.

Muniesa, F. \& Callon, M. (2007), “Economic experiments and the construction of markets.”, In D. Mackenzie, F. Muniesa \& L. Siu (Eds.), Do economists make markets? pp. 163 -1 89, Princeton, NJ: Princeton University Press.

Murray, R. (1999). Creating wealth from waste, London: Demos.

O’Brien, M. (1999), "Rubbish power: toward a sociology of the rubbish society” pp. 262-277 in J. Hearn and S. Roseneil (eds) Consuming Cultures: Power and Resistance, London: Macmillan.

Poon, M. (2009), "From new deal institutions to capital markets: commercial consumer risk scores and the making of subprime mortgage finance”, Accounting, Organizations and Society, Vol. 34, No.5, pp. 654-674.

Preda, A. (2009). "Brief encounters: Calculation and the interaction order of anonymous electronic markets”, Accounting, Organizations and Society, Vol. 34, No.5, pp. 675-693.

Purcell, M. and Magette, W. L. (2010), “Attitudes and behaviour towards waste management in the Dublin, Ireland region”, Waste Management, Vol. 30, 1997-2006.

Qian, W., Burritt, R., and Monroe, G. (2011), "Environmental management accounting in local government: A case of waste management”, Accounting, Auditing and Accountability Journal, Vol. 24, No. 1, pp. 93-128.

Quinn, M., \& Gibney, D. (2018), “Accounting at an Irish maltster-the accounting practices of Bennetts of Ballinacurra in the 1920s and 1930s”, Accounting History Review, Vol. 28, No. 1-2, pp. 61-84.

Reeves, E., and Barrow, M. (2000), "The impact of contracting out on the costs of refuse collection services: The case of Ireland”, Economic and Social Review, Vol. 31, No. 2, pp. 129-150.

Reichenbach, J. (2008)," Status and prospects of pay-as-you-throw in Europe-A review of pilot research and implementation studies”, Waste Management, Vol. 28, No. 12, pp. 28092814.

Reschovsky, J. D., and Stone, S. E. (1994), "Market incentives to encourage household waste recycling: Paying for what you throw away”. Journal of Policy Analysis and Management, Vol. 13, No. 1, pp. 120-139.

Samuel, S., Dirsmith, M. W., and McElroy, B. (2005), "Monetized medicine: from the physical to the fiscal”, Accounting, Organizations and Society, Vol. 30, No.3, pp. 249-278.

Scharff, C., and Vogel, G. (1994), “A comparison of collection systems in European cities”. Waste Management and Research, Vol. 12, No. 5, pp. 387-404.

Stapleton, L., Lehane, M. and Toner, P. (2000), Ireland's environment: a millennium report. Wexford: Environmental Protection Agency.

Strasser, S. (2000). Waste and want: a social history of trash, New York: Owl Books.

Sundin, H., Sundin, H., Brown, D. A., and Brown, D. A. (2017), "Greening the black box: integrating the environment and management control systems" Accounting, Auditing and Accountability Journal, Vol. 30, No. 3, pp. 620-642. 
Swyngedouw, E. (2005), “Governance innovation and the citizen: the janus face of governance beyond-the-state”, Urban Studies, Vol. 42, No. 11, pp. 1991-2006.

Taylor, G. (2001), Conserving the emerald tiger: the politics of environmental regulation in Ireland. Galway: Arlen House.

Warren, L., and Seal, W. (2018), "Using investment appraisal models in strategic negotiation: The cultural political economy of electricity generation”, Accounting, Organizations and Society, Vol. 70, pp. 16-32.

Warren, L., Quinn, M., \& Kristandl, G. (2018), "Investments in power generation in Great Britain c. 1960-2010: The role of accounting and the financialisation of investment decisions”, Qualitative Research in Accounting \& Management, Vol. 15, No. 1, pp. 53-83.

Yearley, S. (1995). Dirty connections: transnational pollution, 143-183 in J. Allen and C Hamnett (eds) A shrinking world, Oxford: Open University Press.

ZeroWaste NZ (2003). Resourceful Communities: A Guide to Resource Recovery Centres in New Zealand, Auckland: ZeroWaste NZ. 


\begin{tabular}{|c|c|c|c|c|}
\hline & $\begin{array}{r}\text { Greyhound } \\
\text { (Dublin) }\end{array}$ & $\begin{array}{r}\text { AES } \\
\text { Meath/Kild } \\
\text { are (rural) }\end{array}$ & $\begin{array}{r}\text { City Bin Co } \\
\text { (Dublin) }\end{array}$ & $\begin{array}{r}\text { City Bin Co } \\
\text { Athlone } \\
\text { (provincial } \\
\text { town) }\end{array}$ \\
\hline \multicolumn{5}{|l|}{ Charges as of May 2017} \\
\hline Monthly Charge & $€ 18.50$ & $€ 25.50$ & $€ 18.00$ & $€ 18.00$ \\
\hline Residual Waste & $€ 2.40$ & - & - & - \\
\hline Organic Waste & - & - & - & - \\
\hline Recyclable Waste & - & - & - & - \\
\hline Total Monthly Charge & $€ 20.90$ & $€ 25.50$ & $€ 18.00$ & $€ 18.00$ \\
\hline Total Annual Charge & $€ 250.80$ & $€ 306$ & $€ 216$ & $€ 216$ \\
\hline \multicolumn{5}{|c|}{ Proposed Pay-By-Weight Charges } \\
\hline Standing Charge & $€ 169$ & $€ 180$ & $€ 155.48$ & $€ 180$ \\
\hline Residual Waste & $\begin{array}{r}600 \mathrm{~kg} \times 35 \mathrm{c} \\
€ 210\end{array}$ & $\begin{array}{r}600 \mathrm{~kg} \mathrm{x} \\
25 \mathrm{c} \\
€ 150\end{array}$ & $\begin{array}{r}600 \mathrm{~kg} \times 20 \mathrm{c} \\
€ 120\end{array}$ & $\begin{array}{r}600 \mathrm{~kg} \times 26 \mathrm{c} \\
€ 156\end{array}$ \\
\hline Organic Waste & $\begin{array}{r}200 \mathrm{~kg} \times 23 \mathrm{c} \\
€ 46\end{array}$ & $\begin{array}{r}200 \mathrm{~kg} \mathrm{x} \\
15 \mathrm{c} \\
€ 30\end{array}$ & $\begin{array}{r}200 \mathrm{~kg} \times 20 \mathrm{c} \\
€ 40\end{array}$ & $\begin{array}{r}200 \mathrm{~kg} \times 16 \mathrm{c} \\
€ 32\end{array}$ \\
\hline Recyclable Waste & - & - & - & - \\
\hline Total Annual Charge & $€ 425.00$ & $€ 360.00$ & $€ 315.48$ & $€ 368.00$ \\
\hline$\%$ increase/decrease in charge & $+69 \%$ & $+18 \%$ & $+46 \%$ & $+70 \%$ \\
\hline
\end{tabular}

Table 1: Comparison of current and proposed Pay-by-Weight household charges (2017) for a selection of waste companies 


\begin{tabular}{|l|r|r|r|r|}
\hline & \multicolumn{1}{|c|}{ A $^{*}$} & $\mathrm{E}$ & $\mathrm{H}$ & $\mathrm{R}$ \\
\hline Charges as of December 2018 & & & & \\
\hline Service Charge & $€ 25.50$ & $€ 29.17$ & $€ 27.98$ & $€ 26.50$ \\
\hline $\begin{array}{l}\text { Residual Waste allowance/cent per } \\
\text { excess kg }\end{array}$ & $70 \mathrm{~kg} / 12 \mathrm{c}$ & $75 \mathrm{~kg} / 22 \mathrm{c}$ & $44 \mathrm{~kg} / 16 \mathrm{c}$ & $80 \mathrm{~kg} / 27 \mathrm{c}$ \\
\hline Organic Waste allowance & $\mathrm{n} / \mathrm{a}$ & $\mathrm{n} / \mathrm{a}$ & $20 \mathrm{~kg} / 12 \mathrm{c}$ & $60 \mathrm{~kg} / 25 \mathrm{c}$ \\
\hline Recyclable Waste allowance & $\mathrm{n} / \mathrm{a}$ & $\mathrm{n} / \mathrm{a}$ & $20 \mathrm{~kg} / 8 \mathrm{c}$ & $\mathrm{n} / \mathrm{a}$ \\
\hline Estimated monthly charges** & & & & $€ 26.50$ \\
\hline Service Charge & $€ 25.50$ & $€ 29.17$ & $€ 27.98$ & $€ 0$ \\
\hline Residual Waste (50kg) & $€ 0$ & $€ 0$ & $€ 9.60$ & $€ 0$ \\
\hline Organic Waste (17kg) & $€ 0$ & $€ 0$ & $€ 0.36$ & $€ 0$ \\
\hline Recyclable Waste (17kg) & $€ 0$ & $€ 0$ & $€ 0.24$ & $€ 318.00$ \\
\hline Total Annual Charge & $€ 306.00$ & $€ 350.04$ & $€ 458.16$ & \\
\hline
\end{tabular}

Table 2: Sample of charges as of December 2018 for a selection of waste companies (source: https://www.dccae.gov.ie/en-ie/news-and-media/press-releases/Pages/Latest-market-review-showsprices-remain-stable-in-December.aspx, own calculations)

* Company identities are not given in published reports.

** Based on annual weights used in Table 1 and assuming 200kg for recyclable waste. 


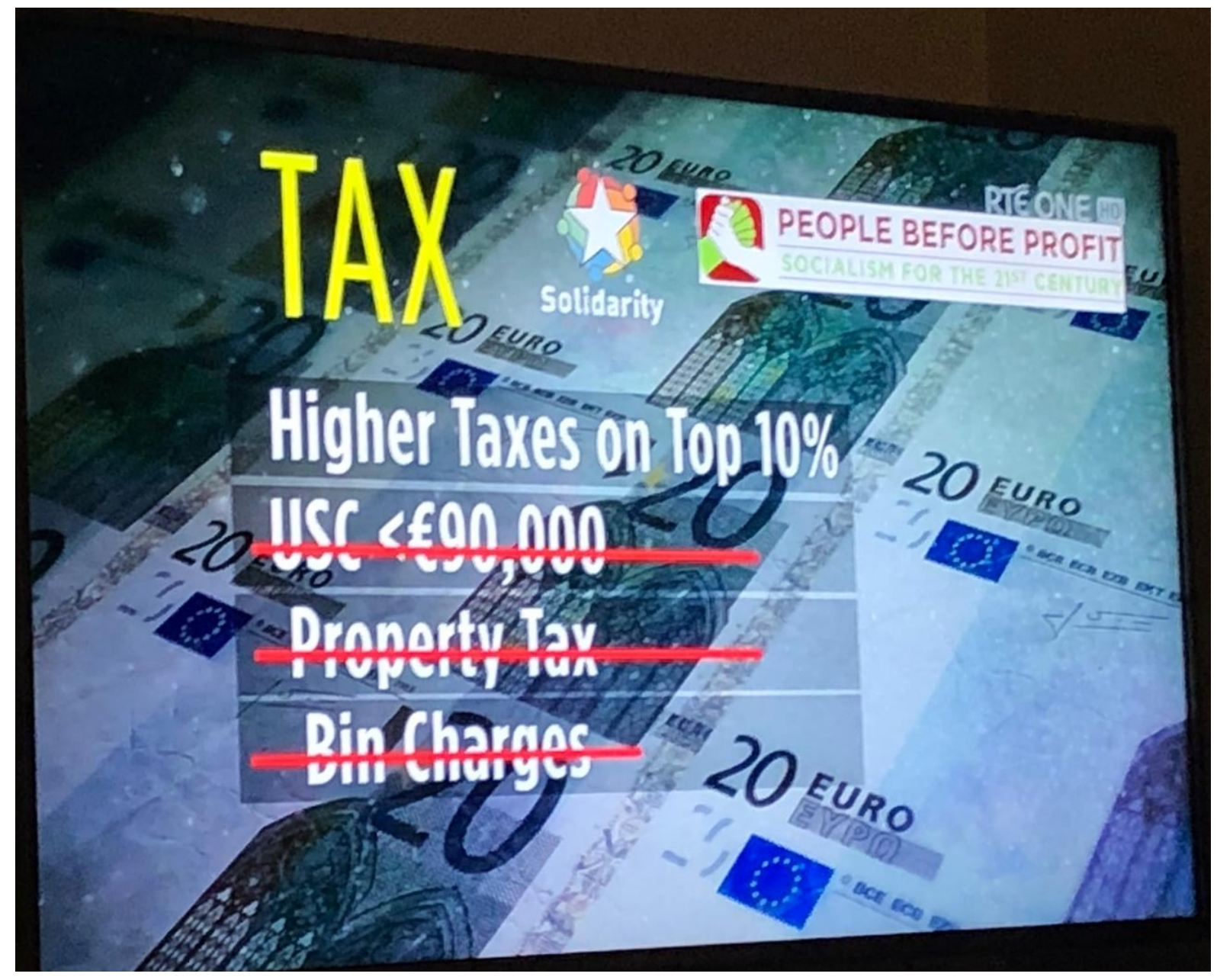

Figure 1 -screen grab from Primetime current affairs programme, January $16^{\text {th }} 2020$. 
That Dáil Éireann

Notes:

- the importance of incentives to encourage recycling so that Ireland's dependency on landfill is decreased

- the importance of a properly funded and consistent awareness and education campaign for the general public about waste management, reduction and recycling

- the need for greater focus on waste reduction initiatives from Government and industry to help consumers create less waste;

- the crucial need for an efficient, cost-effective waste collection processing sector

- the concern about lack of competition in some areas leading to excessive costs

- And that a sudden and unexpected increase in the cost of waste collection will create a disproportionate burden on low-income families and must be avoided;

Condemns:

- unilateral unjustified increases in bin charges;

- and the exclusion of some communities in rural areas from availing of free bins for food waste

Agrees

- that waste collectors need to be open and transparent in relation to their transactions and costs for customers

- that there should be an incentivised, fair and transparent pricing structure that allows for best value for money for the consumer

- $\quad$ to monitor waste collection providers to prevent the formation of cartels

- and that unilateral increases to waste collection charges are unacceptable

And calls for

- the establishment of a new independent waste regulator to establish the true cost associated with the collection and processing of waste by the waste collection industry; ensure an effective, competitive market with fair and transparent pricing; and ensure that households with special needs, including large families and those with incontinence needs, are not unduly penalised where they have already made full efforts to reduce their waste;

- increased funding for local authorities so that they can detect and introduce increased fines for those who dump illegally; and

- increased funding to local authorities to allow them to clean up and dispose of rubbish which is having a negative impact on many urban and rural areas

Figure 2 - extract (edited) from Dáil Éireann debate, 4th July 2017 - Dáil Éireann (2017b). 

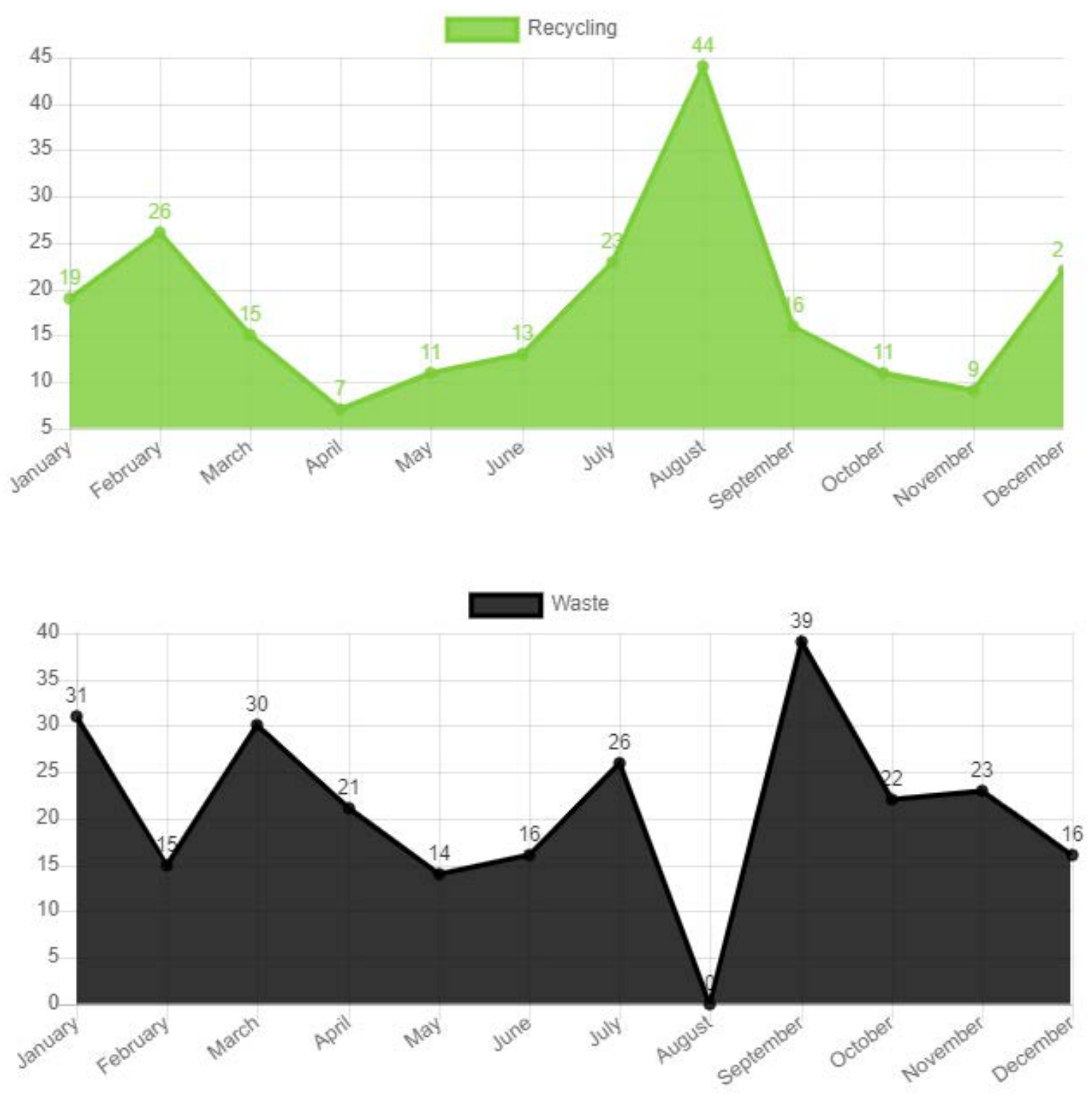

Figure 3 - web-based waste collection statistics - kg per lift, with 80kg monthly allowance (source: authors) 


\section{Appendix 1 - documentary sources}

\begin{tabular}{|c|c|}
\hline \multicolumn{2}{|l|}{ Policy Documents } \\
\hline $\begin{array}{l}\text { National Waste Management Report- 'Changing } \\
\text { our Ways' } 1998\end{array}$ & Environmental Protection Agency (2000) \\
\hline $\begin{array}{l}\text { Delivering Change: Preventing and Recycling } \\
\text { waste, a policy statement }\end{array}$ & Government of Ireland (2002) \\
\hline $\begin{array}{l}\text { Toward a thematic strategy on waste prevention } \\
\text { and recycling. }\end{array}$ & European Commission (2003) \\
\hline $\begin{array}{l}\text { National Waste Management Report- 'Taking } \\
\text { Stock and Moving Forward' }\end{array}$ & Environmental Protection Agency (2004) \\
\hline National Waste Report 2012 & Environmental Protection Agency (2014) \\
\hline \multicolumn{2}{|l|}{ Media Reports } \\
\hline Waste company Panda introduces green bin charges & Irish Times, March $14^{\text {th }}, 2018$ \\
\hline $\begin{array}{l}\text { Dublin city councillors vote against ban on flat rate } \\
\text { bin charges }\end{array}$ & Irish Times, July $3^{\text {rd }}, 2017$ \\
\hline $\begin{array}{l}\text { New bin charges: what do they mean and how } \\
\text { much will they be }\end{array}$ & Irish Times, June $28^{\text {th }}, 2017$ \\
\hline $\begin{array}{l}\text { Mary Lou fires opening salvo in latest round of } \\
\text { 'Utility Wars' }\end{array}$ & Irish Times, June $28^{\text {th }}, 2017$ \\
\hline $\begin{array}{l}\text { How bin charges are set to rise by at least } € 30 \text { - and } \\
\text { it's only the beginning }\end{array}$ & Irish Independent, July 1, 2017 \\
\hline $\begin{array}{l}\text { Watchdog to monitor cost of new waste charges, } \\
\text { Taoiseach says }\end{array}$ & Irish Times, July $4^{\text {th }}, 2017$ \\
\hline $\begin{array}{l}\text { Most people in Cork already pay-by-weight: } \\
\text { Abolition of flat-rate refuse charges will have little } \\
\text { impact in many areas }\end{array}$ & Irish Times, July $5^{\text {th }}, 2017$ \\
\hline Lack of competition widespread in waste sector & Irish Times, July $5^{\text {th }}, 2017$ \\
\hline Waste companies: a collection & Irish Times, June $21^{\text {st }}, 2016$ \\
\hline $\begin{array}{l}\text { Bin charges to be frozen for } 12 \text { months after FF } \\
\text { backs deal }\end{array}$ & Irish Times, June 22 ${ }^{\text {nd }}, 2016$ \\
\hline $\begin{array}{l}\text { Controversy still surrounds pay-by-weight bin } \\
\text { charge system }\end{array}$ & Irish Times, June $24^{\text {th }}, 2016$ \\
\hline $\begin{array}{l}\text { Finding ways to save money on bin charges is not a } \\
\text { waste of time }\end{array}$ & Irish Times, Sept $1^{\text {st }}, 2015$ \\
\hline Low income households wrongly sent charge bills & Irish Times, August 27 $7^{\text {th }}, 2011$ \\
\hline More bin protests due as Higgins, Daly jailed & Irish Times, September $20^{\text {th }}, 2003$ \\
\hline $\begin{array}{l}\text { 2,000 rally in Dublin against bin charge; } \\
\text { Campaigners demand release from prison of } \\
\text { Socialist TD Joe Higgins and Cllr Clare Daly }\end{array}$ & Irish Times, September $23^{\text {rd }}, 2003$ \\
\hline $\begin{array}{l}\text { Anti-bin tax campaign is just the opening shot for } \\
\text { Higgins }\end{array}$ & Irish Times, October $20^{\text {th }}, 2003$ \\
\hline \multicolumn{2}{|l|}{ Parliamentary Records } \\
\hline Dáil Éireann Debate & Recorded Proceedings, June $27^{\text {th }}, 2017$ \\
\hline Dáil Éireann Debate & Recorded proceedings, June $29^{\text {th }}, 2017$ \\
\hline Dáil Éireann Private Members Motion & Official Report, July $4^{\text {th }} 2017$ \\
\hline \multicolumn{2}{|l|}{ Domestic Legislation } \\
\hline \multicolumn{2}{|l|}{$\begin{array}{l}\text { Local Government (Financial Provisions) (No. 2) } \\
\text { Act (1983) }\end{array}$} \\
\hline \multicolumn{2}{|l|}{ Local Government (Dublin) Act (1993) } \\
\hline \multicolumn{2}{|l|}{ Waste Management Act (1996) } \\
\hline \multicolumn{2}{|l|}{ Waste Management (Amendment) Act (1996) } \\
\hline \multicolumn{2}{|l|}{ Protection of the Environment Act (2003) } \\
\hline \multicolumn{2}{|l|}{ European Legislation } \\
\hline EU Directive on Waste (2008/98) & \\
\hline
\end{tabular}




\section{Appendix 2: Timeline of events}

\begin{tabular}{|c|c|c|c|c|c|c|c|c|}
\hline Pre 1995 & 1996 & 1998 & 2001 & 2002 & \multicolumn{2}{|l|}{2003} & & \\
\hline $\begin{array}{l}\text { Some local } \\
\text { authorities } \\
\text { charging for waste } \\
\text { collection, mainly } \\
\text { fixed, outside } \\
\text { Dublin }\end{array}$ & $\begin{array}{l}\text { Waste Management } \\
\text { Act (1996) - all local } \\
\text { authorities } \\
\text { responsible for } \\
\text { household waste } \\
\text { allowed for the } \\
\text { provision of waste } \\
\text { services by private } \\
\text { enterprise }\end{array}$ & $\begin{array}{l}\text { Waste } \\
\text { Management: } \\
\text { Changing Ways } \\
\text { (1998) - European } \\
\text { and government } \\
\text { policy emphasising } \\
\text { waste prevention } \\
\text { and reduced } \\
\text { reliance on landfill }\end{array}$ & $\begin{array}{l}\text { Landfill levy } \\
\text { imposed- passed } \\
\text { on by local } \\
\text { authorities to } \\
\text { private waste } \\
\text { companies }\end{array}$ & $\begin{array}{l}\text { Delivering Change: } \\
\text { Prevention and } \\
\text { Recycling Waste } \\
\text { (2001) - European } \\
\text { and government } \\
\text { policy targets } \\
\text { improved recycling } \\
\text { levels }\end{array}$ & \multicolumn{2}{|c|}{$\begin{array}{l}\text { Protection of the } \\
\text { Environment Act (2003) - } \\
\text { extended \& amended } \\
\text { powers of local } \\
\text { authorities to charge } \\
\text { waste }\end{array}$} & $\begin{array}{l}\text { At thi } \\
\text { collec } \\
\text { a mix } \\
\text { autho } \\
\text { waste } \\
\text { numb } \\
\text { enteri } \\
\text { Wast } \\
\text { fixed }\end{array}$ & $\begin{array}{l}\text { s point waste } \\
\text { tion undertaken by } \\
\text { ture of local } \\
\text { ities \& private } \\
\text { firms; increasing } \\
\text { er of private firms } \\
\text { ng market. } \\
\text { charges are largely }\end{array}$ \\
\hline 2004 & & & 2015 & 2017 & & & & 2018 \\
\hline $\begin{array}{l}\text { Taking Stock and } \\
\text { Moving Forward } \\
\text { (2004) - EU } \\
\text { calling for } \\
\text { 'Polluter Pays' } \\
\text { principal to be } \\
\text { applied }\end{array}$ & $\begin{array}{l}\text { Pay by volume is } \\
\text { introduced in } \\
\text { many areas } \\
\text { outside Dublin } \\
\text { Private waste } \\
\text { companies } \\
\text { increasing charges }\end{array}$ & $\begin{array}{l}\text { Collection of } \\
\text { domestic waste } \\
\text { fully privatised- } \\
\text { private companies } \\
\text { enter the Dublin } \\
\text { market- many } \\
\text { offering } \\
\text { competitive rates }\end{array}$ & $\begin{array}{l}\text { Environment } \\
\text { (Miscellaneous } \\
\text { Provisions) Act } \\
\text { (2015) - } \\
\text { Introduction of a } \\
\text { pay by weight } \\
\text { scheme } \\
\text { incorporating } \\
\text { minimum } \\
\text { mandatory fees by } \\
\text { July } 2016\end{array}$ & $\begin{array}{l}\text { Amidst public } \\
\text { backlash an } \\
\text { already unstable } \\
\text { government } \\
\text { freezes new } \\
\text { waste charges } \\
\text { until July } 2017\end{array}$ & $\begin{array}{l}\text { Enacting of } \\
\text { pay by weight } \\
\text { scheme per } \\
\text { the } 2015 \text { Act } \\
\text { Dublin } \\
\text { customers } \\
\text { experience } \\
\text { significant price } \\
\text { increases } \\
\text { Political calls } \\
\text { for more } \\
\text { transparency } \\
\text { from private } \\
\text { waste industry }\end{array}$ & $\begin{array}{l}\text { Government } \\
\text { abolishes min } \\
\text { mandatory fee } \\
\text { allowing priva } \\
\text { companies to } \\
\text { their own } \\
\text { incentivised } \\
\text { charging sche } \\
\text { Half of housel } \\
\text { still paying a } \\
\text { mostly in Dub }\end{array}$ & $\begin{array}{l}\text { fer } \\
\text { lds } \\
\text { t fee- } \\
\text { e }\end{array}$ & $\begin{array}{l}\text { Most companies } \\
\text { charge a standard } \\
\text { service charge with } \\
\text { additional charges } \\
\text { per kg or lift }\end{array}$ \\
\hline
\end{tabular}

